\title{
A spatial gradient of expression of a cAMP-regulated prespore cell-type-specific gene in Dictyostelium
}

\author{
Linda Haberstroh and Richard A. Firtel ${ }^{1}$ \\ Department of Biology, Center for Molecular Genetics, M-034, University of California, San Diego, La Jolla, California 92093 \\ USA
}

Previously, we identified a class of genes in Dictyostelium that are prespore cell-type specific in their expression in the multicellular aggregate and are inducible by cAMP acting through cell-surface cAMP receptors. In this paper, we report the cloning and analysis of the regulatory regions controlling the expression of one such gene that encodes a spore coat protein, SP60. By use of a fusion of the firefly luciferase gene and Escherichia coli lacZ [expresses $\beta$-galactosidase ( $\beta$-gal)], we have identified cis-acting regions required for proper spatial and temporal expression in multicellular aggregates and for cAMP induction in shaking cell culture. Deletion analysis suggests that a CA-rich element (CAE) and surrounding sequences present three times within the 5'flanking sequence are required for proper regulation. SP60-lacZ fusions that include all three of these regions express lacZ only in the posterior $\sim 85 \%$ of migrating slugs (prespore zone). Studies show that $S P 60$ is expressed during mid to late aggregation, and SP60-lacZ-positive cells are spatially localized as a doughnut-shaped ring within the forming aggregate. Cells within the skirt that surrounds the aggregate and that are still migrating into the aggregate do not stain. Sequential 5' deletions of CAEs and surrounding regions affect the expression level of SP60-luciferase in response to developmental signals and cAMP, as well as the spatial pattern of SP60-lacZ. Deletion of the first (most 5') of these regions restricts the spatial expression of SP60-IacZ fusions to the anterior of the prespore zone. When both the first and second regions are removed, the expression level drops, and the staining is restricted to the prespore/prestalk boundary. Furthermore, the staining pattern that is seen with these two deletions is present as a gradient from anterior to posterior within the prespore zone. Deletion of all three regions results in a loss of both cAMP and developmentally induced expression. These results suggest the presence of a gradient within the prespore zone that differentially affects the activity of promoters containing different numbers of response elements.

[Key Words: Dictyostelium; cAMP-regulated gene; regulatory regions; SP60]

Received October 31, 1989; revised version accepted January 31, 1990.

Dictyostelium discoideum grows as a single-cell vegetative amoeba. Cells remain in this vegetative state until food is depleted. On starvation, cells initiate a multicellular developmental program in which $\sim 10^{5}$ cells form a multicellular aggregate. During this time, the cells do not feed or divide; thus, cell division and multicellular differentiation are separated in this organism. The aggregation process is mediated chemotactically by extracellular cAMP that interacts with cell-surface receptors to activate two intracellular signal transduction pathways: one involving a cAMP relay pathway and one controlling cell motility and induction of genes whose products are required for aggregation (Janssens and van Haastert 1987; Firtel et al. 1989). A loose aggregate is formed by $10 \mathrm{hr}$. By $15-16 \mathrm{hr}$, a migrating slug or pseudoplasmodium develops that culminates to form a mature fruiting body containing $\sim 85 \%$ spores and $\sim 15 \%$ stalk cells. The slug contains predominantly two cell types that are

'Corresponding author. spatially localized: The anterior $15 \%$ contains prestalk cells, whereas the posterior $85 \%$ contains predominantly prespore cells (Loomis 1982). The mechanisms regulating whether a vegetative cell eventually differentiates into a prestalk/stalk cell or a prespore/spore cell are partially understood. Cells starved early in the cell cycle ( $S$ and early $G_{2}$; there is no detectable $G_{1}$ ) preferentially differentiate into prestalk cells, whereas those starved in mid and late $G_{2}$ differentiate into prespore cells (Weijer et al. 1984; Gomer and Firtel 1987b). After the pseudoplasmodium has formed, cAMP, adenosine, $\mathrm{NH}_{4}{ }^{+}$, and the morphogen DIF all play roles in regulating gene expression, patterning, and subsequent differentiation (see Mehdy et al. 1983; Chisholm et al. 1984; Williams et al. 1984; Mehdy and Firtel 1985; Schaap and van Driel 1985; Gomer et al. 1986b; Oyama and Blumberg 1986; Schaap and Wang 1986; Williams et al. 1987, 1988; Wang et al. 1988).

We and others have isolated cDNA and genomic clones for a number of genes preferentially expressed in 
either prestalk or prespore cells. We have used these clones as probes to examine the regulatory pathways controlling cell-type-specific gene expression (Barklis and Lodish 1983; Mehdy et al. 1983; Pears et al. 1985; Dowds and Loomis 1986; Hong and Loomis 1988; Fosnaugh and Loomis 1989). By RNA blot hybridization, prestalk gene expression is first detected as the aggregate is forming and is maximal at the tight aggregate/pseudoplasmodium stages, whereas prespore RNA is first detected at the loose/tight aggregate stage and is maximal in the pseudoplasmodium/early culminant stages (Mehdy et al. 1983; Saxe and Firtel 1986). The gene product for one prespore gene, that for the prespore coat protein SP70 (see below), has been specifically localized in the posterior prespore cells in migrating slugs and in maturing spore cells (Gomer et al. 1986a). Both prestalk and prespore genes can be induced in single-cell culture by cAMP (Barklis and Lodish 1983; Mehdy et al. 1983; Mehdy and Firtel 1985; Saxe and Firtel 1986). Analyses using pharmacological agents, cAMP analogs, and mutants that affect signal transduction have indicated that induction of both prestalk and prespore gene expression by cAMP is mediated through cell-surface receptors that are coupled to G proteins (Schaap and van Driel 1985; Gomer et al. 1986b; Haribabu and Dottin 1986; Oyama and Blumberg 1986; Kimmel 1987; Firtel et al. 1989). Recent studies suggest that diazoglycerol (DAG) and 1,4,5-inositol triphosphate $\left(1,4,5-\mathrm{IP}_{3}\right)$ are the second messengers involved in this induction (Ginsburg and Kimmel 1990). Although some of the extracellular (cAMP) and intracellular (DAG and 1,4,5- $\mathrm{IP}_{3}$ ) messengers have similar effects in the regulation of the expression of these genes, other studies indicate that the intracellular pathways regulating the expression of these two classes of genes are different (Gomer et al. 1985; Mehdy and Firtel 1985; Blumberg et al. 1988; Spek et al. 1988).

Molecular analysis has identified the cis-acting elements regulating cAMP induction and developmental expression, as well as a developmentally regulated trans-acting factor controlling their expression of the cAMP-inducible early prestalk genes (Datta and Firtel 1987, 1988; Pears and Williams 1987, 1988; Hiorth et al. $1989,1990)$. However, no information is available on the molecular requirements for prespore gene expression, nor is the spatial expression of these genes within the multicellular aggregate understood. To understand better the regulatory pathways controlling prespore celltype-specific gene expression, we have now examined the cis-acting regulatory region of the spore coat SP60, which is one of a set of three proteins (SP60, SP70, and SP96) that make up the majority of the proteinaceous component of the spore coat (Devine et al. 1983; Erdos and West 1989). SP60 and SP70 gene expression is coordinately regulated at the level of transcription during multicellular development in wild-type cells and in a number of mutant strains affected in their temporal pattern of differentiation, and in response to cAMP and cAMP analogs in shaking culture (Mehdy et al. 1983; Gomer et al. 1985, 1986; Mehdy and Firtel 1985; Saxe and Firtel 1986; Fosnaugh and Loomis 1989|. Within the pseudoplasmodium and early culminant, these proteins are localized in vacuoles in prespore cells as a layer covering the internal side of the vacuole membrane. During the maturation of spores during culmination, these vacuoles fuse with the plasma membrane (Devine et al. 1983; Erdos and West 1989). As a result, the inside of the prespore vacuole becomes the spore coat extracellular matrix. By use of $l a c Z$ and firefly luciferase gene fusions, we describe the spatial patterning of the prespore zone and show that $650 \mathrm{bp}$ of the 5 -flanking region contains all of the necessary signals for proper cAMP regulation and spatially and temporally correct cell-type-specific expression. This region contains a short CA-rich element (CAE) that is repeated three times. Sequential $5^{\prime}$ deletions of each repeat and surrounding sequences, as well as some internal deletions that remove these regions, result in substantial reductions in cell-type-specific expression. In addition, sequential deletion of these regions causes an anterior-to-posterior decreasing gradient of expression within the prespore zone, suggesting the presence of some type of gradient within this region of the aggregate. Possible models for this differential expression of SP60 are presented.

\section{Results}

\section{Cloning and structure of the SP60 prespore gene}

The cDNAs 3-E2 and 9-C3 were originally identified as being complementary to 1.8 -kb mRNAs preferentially expressed in prespore cells, and they were shown to be inducible by cAMP in shaking culture (Mehdy et al. 1983; S. Datta and R.A. Firtel, unpubl.). Although the two cDNAs do not cross-hybridize, they both hybridize to the same genomic fragments (see below). Because both cDNAs are substantially shorter than the mRNA, they were presumed to be nonoverlapping, partial cDNA clones. The two cDNAs were used to isolate the prespore gene from two genomic libraries, and two overlapping genomic clones were obtained (see Materials and methods). The cDNAs within the genomic clones were localized by restriction mapping and DNA blot hybridization. The polarity of transcription was determined through the use of SP6- and $\mathrm{T}_{7}$-derived strand-specific RNA hybridization probes (see Materials and methods). The possibility of other transcription units within the genomic fragments was ruled out by use of different regions of the genomic clones as hybridization probes against RNA isolated from various times in Dictyostelium development. A single transcription unit was identified that mapped to the region complementary to the two cDNAs (data not shown; see Fig. 3). A map of the genomic clone indicating the location of the prespore gene and positions of the two cDNA clones is shown in Figure 1.

Approximately $2 \mathrm{~kb}$ of the genomic clone and a portion of the cDNA clone 3-E2 that maps toward the 5' end of the prespore transcription unit were sequenced (see Fig. 2). A single open reading frame in the cDNA was identified that was colinear with the sequence of 


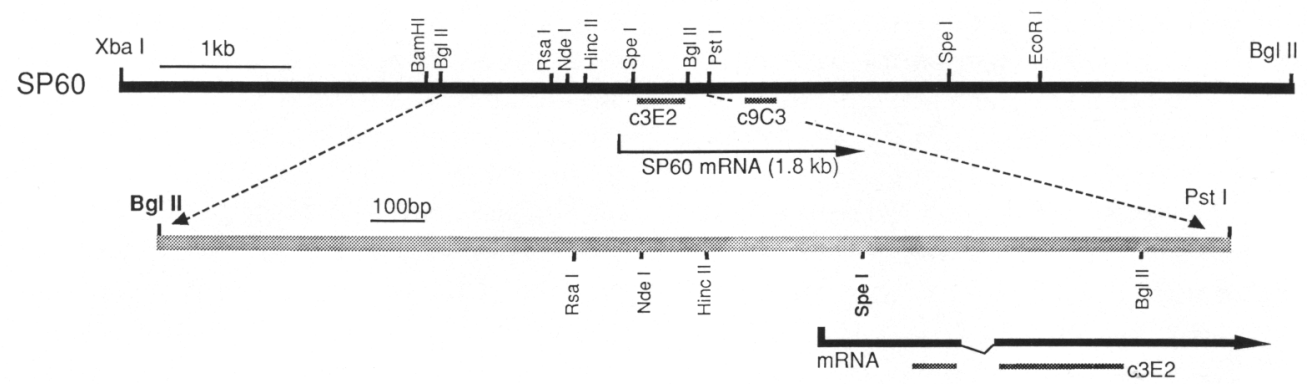

Figure 1. Genomic map of the SP60 gene. The structure and partial restriction maps of two overlapping genomic clones (see text) containing the SP60 gene are presented. The location of the coding region, the start of transcription, and a mapped exon in the amino-terminal region of the SP60-coding sequence are indicated. The location of the 9-C3 and 3-E2 cDNAs are shown. The genomic clones overlap from the BgIII site to the PstI site in the center of the map (the region between the two cDNAs). One genomic clone extended from the $\mathrm{XbaI}$ site to the PstI site. The second clone was the BgIII fragment from the BglII site immediately $5^{\prime}$ of the $P s t I$ site to the BgIII site at the $3^{\prime}$ end of the cloned region. (For details of the cloning procedures, see Materials and methods.) The positions of homology to the two cDNA clones (c3E2 and c9C3) are shown. Also presented is an expansion of the region between the BgIII site at position -1335 (relative to the cap site) and the $P$ st I site within the coding region. The sequence of this fragment is presented in Fig. 2 . The position of several unique restriction sites that were used for deletion constructs are shown. The region between the BglII and SpeI sites shown in boldface type is a reference point for the deletion map shown in Fig. 5.

the genomic clone except for the presence of a 120-bp intron within this region of the genomic clone. The intron, as with other noncoding regions, is very AT-rich and has $5^{\prime}$ donor and $3^{\prime}$ acceptor sequences that agree with the consensus splice sequence for Dictyostelium genes (Kimmel and Firtel 1983). The $5^{\prime}$ end of the mRNA was determined by $\mathrm{S} 1$ nuclease mapping (see Fig. $3 \mathrm{~A}$ ) and is marked on the sequence (see Fig. 2). A putative TATA box lies at -36 . Analysis of the extremely AT-rich $5^{\prime}$-upstream regions shows three homologous CA-rich sequences (which we designate CAE) (CACA$\mathrm{CA}^{\mathrm{C}}{ }_{\mathrm{T}} \mathrm{C}_{\mathrm{T}} \mathrm{C}_{\mathrm{A}} \mathrm{ACACAC}$ ) that have been labeled box 1, box 2 , and box 3 . These CACA boxes are followed by an ${ }^{A} \mathrm{~T} T$ $\mathrm{CAN}^{\mathrm{A}} \mathrm{T}$ sequence $\sim 15-30 \mathrm{bp}$ downstream.

Analysis of the derived protein sequence for the region sequenced indicates the presence of four repeats of six amino acids (GDWNNN) in the amino-terminal region that is preceded by a putative transmembrane leader sequence. This is followed by a region of $\sim 70$ amino acids that is rich in proline and cysteine. A search of the literature indicated that the 6-amino-acid repeat is identical

Figure 2. Sequence of 5 'flanking region and amino-terminalcoding sequence of SP60. The ATG translation initiation codon was determined from the open reading frame that is contiguous through the 3-E2 cDNA. The A-rich sequence $5^{\prime}$ to the ATG initiation codon is similar to that present in other Dictyostelium genes (Kimmel and Firtel 1983). The intron, determined from the discontinuity of the genomic and cDNA sequence, is shown. The three CACA-rich sequences (CAE boxes) are labeled and numbered $1-3,5^{\prime} \rightarrow 3^{\prime}$. The TATA box at nucleotide -36 is underlined, and the $5^{\prime}$ start of transcription as determined from S1 mapping is shown $(+1)$. The derived open reading frame is indicated. The position of the $5^{\prime}$ deletion end points and the unique RsaI and NdeI restriction sites used for mapping of the cis-regulatory regions are shown, as is the fusion point $\left(3^{\prime} \Delta 2\right)$ for all luciferase and lacZ constructs.

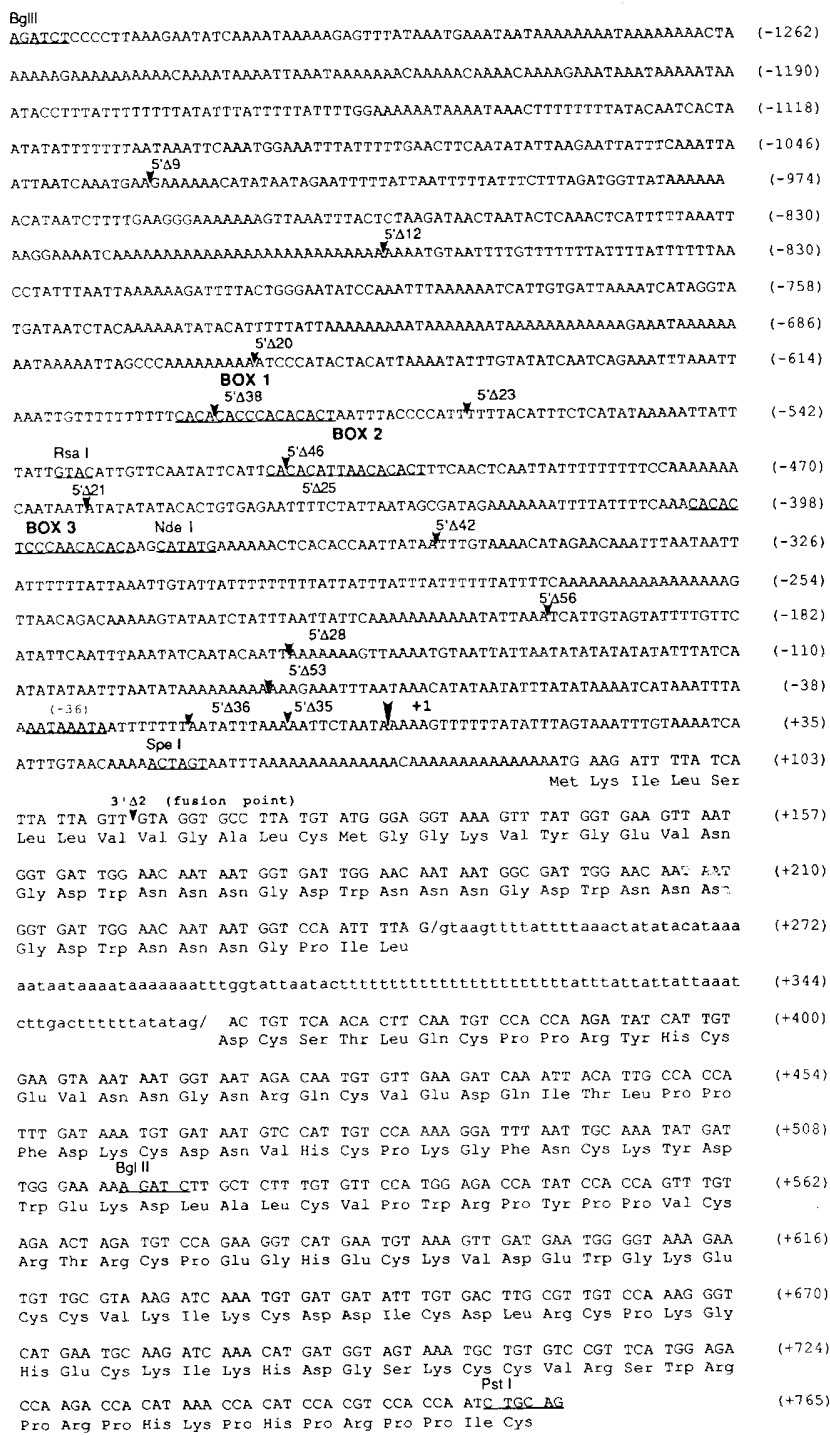


to that obtained by Loomis and collaborators from a partial protein sequence and derived amino acid sequence of a short cDNA encoding the amino-terminal region of
SP60 (Dowds and Loomis 1986; Hong and Loomis 1988). Both the identity of the derived amino acid sequence with the protein amino acid sequence and the prespore-

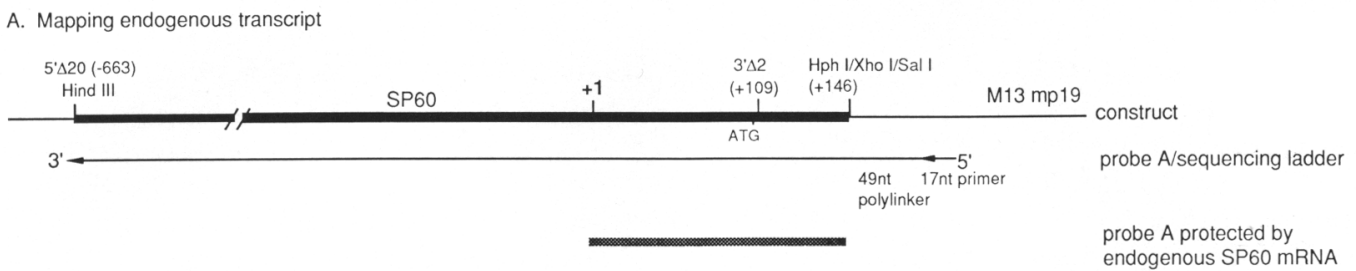

B. Mapping fusion gene transcript
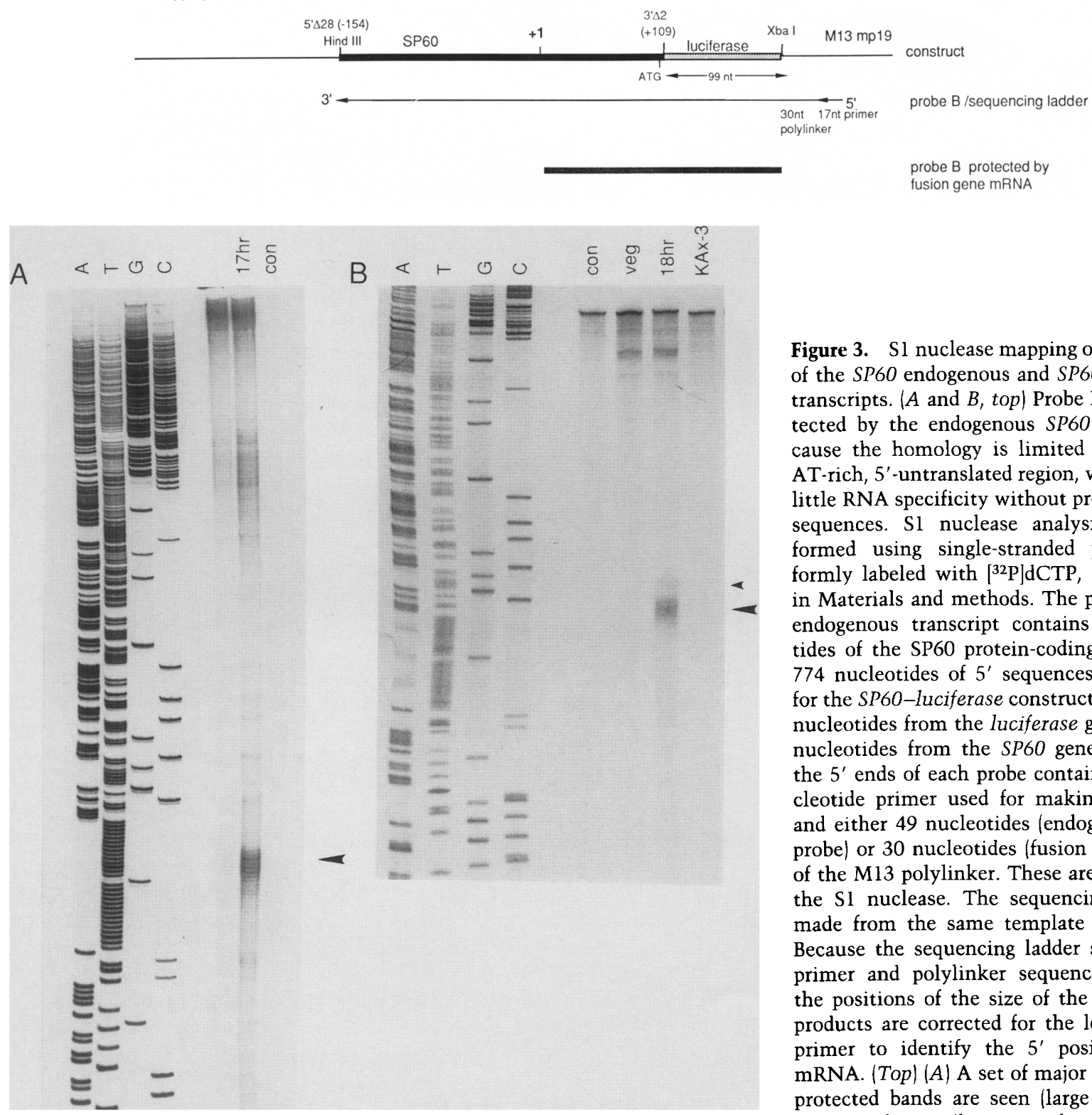

Figure 3. Sl nuclease mapping of the $5^{\prime}$ ends of the SP60 endogenous and SP60-luciferase transcripts. $(A$ and $B$, top) Probe B is not protected by the endogenous SP 60 mRNA because the homology is limited to the very AT-rich, 5'-untranslated region, which shows little RNA specificity without protein coding sequences. S1 nuclease analysis was performed using single-stranded probes uniformly labeled with $\left[{ }^{32} \mathrm{P}\right] \mathrm{dCTP}$, as described in Materials and methods. The probe for the endogenous transcript contains 37 nucleotides of the SP60 protein-coding region and 774 nucleotides of $5^{\prime}$ sequences. The probe for the SP60-luciferase construct contains 99 nucleotides from the luciferase gene and 265 nucleotides from the SP60 gene. Note that the $5^{\prime}$ ends of each probe contain the 17-nucleotide primer used for making the probe and either 49 nucleotides (endogenous RNA probe) or 30 nucleotides (fusion RNA probe) of the M13 polylinker. These are digested by the S1 nuclease. The sequencing ladder is made from the same template and primer. Because the sequencing ladder still has the primer and polylinker sequences attached, the positions of the size of the S1 nuclease products are corrected for the length of the primer to identify the $5^{\prime}$ position of the mRNA. (Top) (A) A set of major S1 nucleaseprotected bands are seen (large arrowhead); $(B)$ a set of major (large arrowhead) and minor (small arrowhead) bands are seen. ( $A$ and $B$, bottom) Gel analysis. The sequencing ladder is shown in lanes ATGC in both $A$ (endogenous transcript) and $B$ (SP60-luciferase transcript). (A) Lanes $17 \mathrm{hr}$ indicate the probe hybridized to RNA from KAx-3 cells developed for $17 \mathrm{hr}$ and then digested with Sl nuclease. Lane con is the probe hybridized to $E$. coli tRNA and then digested with $\mathrm{S} 1 \mathrm{nuclease}$. $(B)$ Lanes veg and $18 \mathrm{hr}$ indicate the probe hybridized to RNA from vegetative and 18-hr developed cells, respectively, and digested with S1 nuclease. Lane KAx-3 is the probe hybridized to RNA from 17-hr untransformed cells (strain KAx-3) and then digested with $\mathrm{S} 1$ nuclease. Lane con is as in $A$. 
specific expression of 3-E2/9-C3 complementary mRNA indicates that the isolated gene encodes the spore coat protein SP60. The amino acid sequence of purified SP60 begins with the glycine corresponding to amino acid 23 in our derived amino acid sequence (Dowds and Loomis 1986), suggesting that the leader is removed during processing. The four hexa-amino acid repeats and the proline- and cysteine-rich region that follows may be important motifs required for building a complex spore coat structure. The hydrophobic leader sequence is presumably involved in membrane insertion and subsequent localization of the SP60 coat protein in the prespore vesicles. The $S P 60$ gene has also been cloned, and the coding region has been sequenced by Fosnaugh and Loomis (1989).

Figure 4 shows the developmental kinetics of SP6O mRNA and that of another major prespore protein, SP70. SP60 mRNA is not expressed in vegetative or early developing cells and can first be detected in cells at $10 \mathrm{hr}$ of development, shortly after the aggregate is formed. It is maximally expressed at the slug and culminant stages. SP70 mRNA shows a slightly different pattern. It is first detectable at $12-15 \mathrm{hr}$, peaks at $22.5 \mathrm{hr}$, and decreases slightly by $25 \mathrm{hr}$. Because both the SP 60 and SP70 probes are being hybridized to the same blot, we do not believe that these differences are due to experimental variations. This is consistent with previous data from our laboratory (Mehdy et al. 1983; Saxe and Firtel 1986) on SP60 and SP70 expression and similar to that of Loomis and co-workers (Hong and Loomis 1988; Fosnaugh and Loomis 1989), although they observe a greater coordination of SP60 and SP70 expression.

\section{Identification of cis-acting regulatory regions}

To identify the cis-acting regulatory regions of SP60, sequences between the upstream BglII site, 1335 bp 5' from the cap site, and a linker inserted after codon 7

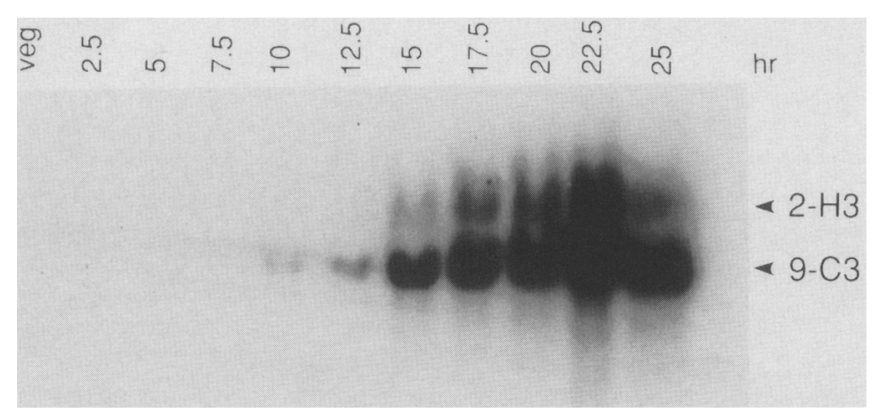

Figure 4. Developmental time course of expression of SP60 and SP70 mRNAs. A developmental time course was performed as described in Materials and methods. Cells were plated for morphological development and harvested at the times indicated. RNA was extracted and analyzed by RNA blot hybridization. RNA blots were hybridized with 9-C3 (SP60 probe) and 2-H3 (SP70 probe) cDNA inserts (for details, see Materials and methods). Aggregation occurred between 7 and $10 \mathrm{hr}$, the tight aggregate stage was $\sim 12 \mathrm{hr}$, and early culminants were harvested at $\sim 18 \mathrm{hr}$. were fused in-frame to the firefly luciferase reporter gene in a Dictyostelium transformation vector (see Fig. 9). This plasmid was used as a basis for constructing a series of ExoIII $5^{\prime}$ deletions that were capped at the 5' end with a HindIII linker. The structure of the vector with the positions of the deletions used in subsequent studies is shown in Figure 5. The complete structure and a partial restriction map of the vector are shown in Figure 9A. The SP60-luciferase fusions were transformed into the wild-type axenic strain $\mathrm{KAx}-3$, and stable transformants were isolated.

To examine the temporal pattern of expression, transformants were plated for development on filters. A partial developmental time course of luciferase specific activity in cells carrying the parent SP60-luciferase gene construct $(2 \mathrm{IN})$ is shown in Table 1 . The expression of the promoterless $2 \mathrm{R} 10$ vector is also presented. Expression of an Actin15-luciferase fusion gene [VIILuc (Howard et al. 1988)] was included as an internal control for the assay. The expression of the parent (2IN) fusion gene containing $1.3 \mathrm{~kb}$ of $S P 60$ upstream is highly developmentally regulated, like that of the endogenous gene. There is a very low, but detectable, level of luciferase activity in vegetative cells (see Discussion). By $9 \mathrm{hr}$, as the aggregate is forming, luciferase specific activity starts to increase, is very high at $18 \mathrm{hr}$, and increases another two- to fivefold by $23 \mathrm{hr}$ late in culmination (data for $23 \mathrm{hr}$ not shown). As shown in the RNA blot in Figure 4, SP60 RNA levels are maximal between 20 and $23 \mathrm{hr}$. The increase in luciferase specific activity from the level in vegetative cells is $\sim 10^{4}$ - to $10^{5}$-fold, and the maximal specific activity of the parental construct is similar to that of VIILuc, which uses the Actin 15 promoter, one of the strongest Dictyostelium promoters. This is consistent with the high level of accumulation of the SP60 mRNA and is not unexpected for a major spore structural protein.

The $5^{\prime}$ end of the gene fusion mRNA was determined by S1 nuclease experiments (Berk and Sharp 1977) with a 409-nucleotide probe from the $\mathrm{XbaI}$ site at nucleotide +99 of the luciferase-coding sequence through nucleotide -154 (construct $5^{\prime} \Delta 28$ ) of the $S P 605^{\prime}$ flanking sequence isolated from the SP60-luciferase fusion gene and includes some polylinker sequences. The cap site mapped within 5 nucleotides of the cap site of the endogenous SP60 mRNA (see Figs. 2 and 3B).

We then examined the expression of the different SP60-luciferase constructs in vegetative cells and in cells at $18 \mathrm{hr}$ of development. In some experiments, expression at $10 \mathrm{hr}$ of development, a time when SP60 mRNA can first be detected on RNA blots, was also assayed. The data from several experiments are presented as luciferase specific activity and as a percentage of the level at $18 \mathrm{hr}$ of construct $5^{\prime} \Delta 20$ (see Table 1). $2 \mathrm{R} 10$ and VIILuc were used as internal controls in all transformations and in all developmental studies. In examining the results, we note that there is experiment-to-experiment variability in the levels of luciferase activity when cells transformed with a specific construct are assayed. This is due to variability in synchrony of the developing cells 
in different experiments and to the very rapid rate of increase in luciferase activity over time in the developmental periods that were assayed. The overall qualitative and quantitative effects of the deletions on SP6Oluciferase expression are consistent.

The general pattern of expression with the deletion constructs suggests four major classes of deletion, A-D, defined by the level of expression (Table 1; Fig. 5). Deletions removing $\sim 670 \mathrm{bp}$ from the 5 '-flanking sequence of the parent construct $\{2 I N,-1335)$ to $-663\left(5^{\prime} \Delta 20\right)$ result in a three- to fivefold reduction in the level of expression at $18 \mathrm{hr}$ and a decrease in vegetative expression and have been grouped as class $\mathrm{A}$. The next two deletions $\left\langle 5^{\prime} \Delta 38\right.$ and $5^{\prime} \Delta 23$, class $\left.B\right|$ remove another $\sim 80 \mathrm{bp}$ of $5^{\prime}$ sequence and a major portion or all of the first $\mathrm{CAE}$ (box 1), as well as intervening sequences, and show an $\sim 20$-fold drop in the level of expression. Deletions $5^{\prime} \Delta 21$ and $5^{\prime} \Delta 25$ (class $\mathrm{C}$ ) remove $\sim 100 \mathrm{bp}$ more, including box 2 , and result in a further $\sim 50$-fold drop in activity. Although the luciferase specific activity is $<0.1 \%$ that of

Table 1. Effect of $5^{\prime}$ deletions on luciferase specific activity

\begin{tabular}{|c|c|c|c|c|c|c|}
\hline & \multirow[b]{2}{*}{ Construct $^{\mathrm{a}}$} & \multicolumn{4}{|c|}{$\begin{array}{l}\text { Activity at specified developmental times } \\
\text { (LU/mg protein) }\end{array}$} & \multirow{2}{*}{$\begin{array}{l}\text { Maximum } \\
\text { sp. act. }(\%)\end{array}$} \\
\hline & & Experiment & $t=0 \mathrm{hr}$ & $t=10 \mathrm{hr}$ & $t=18 \mathrm{hr}$ & \\
\hline \multirow{8}{*}{ Class A } & parent $\mid-1335\}$ & a & 6 & 254 & $4.8 \times 10^{6}$ & 480 \\
\hline & & $b$ & 215 & n.d. & $1.3 \times 10^{6}$ & 542 \\
\hline & & $\mathrm{c}$ & 0.2 & 74 & $1.25 \times 10^{6}$ & 230 \\
\hline & $5^{\prime} \Delta 9(-1033)^{a}$ & & - & - & - & 330 \\
\hline & $5^{\prime} \Delta 12(-866)^{a}$ & & - & - & - & 290 \\
\hline & $5^{\prime} \Delta 20(-663)$ & a & 22 & $3.8 \times 10^{3}$ & $1.0 \times 10^{6}$ & 100 \\
\hline & & $\mathrm{b}$ & 46 & n.d. & $2.4 \times 10^{5}$ & 100 \\
\hline & & $\mathrm{c}$ & 0.5 & 120 & $5.4 \times 10^{5}$ & 100 \\
\hline \multirow{4}{*}{ Class B } & $5^{\prime} \Delta 38(-595)$ & $\mathrm{b}$ & 13 & n.d. & $1.1 \times 10^{4}$ & 4.6 \\
\hline & $5^{\prime} \Delta 23(-570)$ & $\mathrm{a}$ & 24 & 130 & $9.6 \times 10^{3}$ & 1.0 \\
\hline & & $\mathrm{b}$ & 35 & n.d. & $1.4 \times 10^{4}$ & 5.8 \\
\hline & & $\mathrm{c}$ & 0.1 & 51 & $3.0 \times 10^{4}$ & 5.5 \\
\hline \multirow{5}{*}{ Class C } & $5^{\prime} \Delta 46(-516)$ & $\mathbf{a}$ & 26 & n.d. & $4.8 \times 10^{3}$ & $5 \times 10^{-1}$ \\
\hline & $5^{\prime} \Delta 21(-464)$ & $\mathrm{a}$ & 6 & 20 & 99 & $1.0 \times 10^{-2}$ \\
\hline & & $\mathrm{b}$ & 4.8 & n.d. & 168 & $7 \times 10^{-2}$ \\
\hline & & c & 0.14 & 27 & $\left(3 \times 10^{3}\right)^{b}$ & $5 \times 10^{-1}$ \\
\hline & $5^{\prime} \Delta 25(-449)$ & $\mathrm{b}$ & 3.8 & n.d. & 58 & $2.4 \times 10^{-2}$ \\
\hline \multirow{8}{*}{ Class D } & $5^{\prime} \Delta 42(-357)$ & $\mathrm{b}$ & 4.1 & n.d. & 9.7 & $3.8 \times 10^{-3}$ \\
\hline & $5^{\prime} \Delta 56(-203)$ & $\mathrm{b}$ & 2.5 & n.d. & 2.0 & $8 \times 10^{-4}$ \\
\hline & $5^{\prime} \Delta 28(-154)$ & a & 8 & 1.6 & 3.6 & $3.6 \times 10^{-3}$ \\
\hline & $5^{\prime} \Delta 53(-90)$ & $\mathrm{a}$ & 4.5 & n.d. & 4.4 & $4 \times 10^{-4}$ \\
\hline & $\left.5^{\prime} \Delta 36 \mid-20\right)$ & a & 24 & n.d. & 5.6 & $6 \times 10^{-4}$ \\
\hline & $5^{\prime} \Delta 35(-10)$ & a & 1.0 & 2.2 & 1.3 & $1 \times 10^{-4}$ \\
\hline & 2R10 (no promoter) & a & 3 & 2.4 & 0.3 & $3 \times 10^{-5}$ \\
\hline & VIILUC & a & $8.8 \times 10^{6}$ & $9.5 \times 10^{6}$ & $9.8 \times 10^{6}$ & 980 \\
\hline
\end{tabular}

Luciferase activity in light units (LU) per microgram of total protein is given for stable transformants during multicellular development. Three developmental times were assayed: At $0 \mathrm{hr}$, the cells are vegetative and growing logarithmically; the 10-hr time point corresponds to a loose aggregate; the 18 -hr time point represents early to mid-culmination. At $18 \mathrm{hr}$, the cells develop very rapidly and there is some asynchrony in the population. In each experiment, cells were harvested at approximately the same point in development, as determined visually. Data from three different experiments $(a, b, c)$ are presented. For each time point, the absolute specific activity of luciferase (LU/ $\mu$ g protein) is given. However, because of experiment-to-experiment variability due to the biology of the system, data were not averaged. Construct $5^{\prime} \Delta 20$ and the promoterless construct $(2 \mathrm{R} 10)$ were used as internal controls in every experiment. To allow comparisons between experiments and to quantitate the effect of each deletion on reporter gene activity, the level of expression for each construct is also presented as a percentage of the level of $5^{\prime} \Delta 20$ luciferase specific activity for that particular experiment. Cells transformed with an Actin 15-luciferase fusion gene [VIILuc (Howard et al. 1988)] were used in all assays as an internal control for the luminometer; these results are given for experiment a only. The parent (2IN), $5^{\prime} \Delta 23,5^{\prime} \Delta 21,5^{\prime} \Delta 42,5^{\prime} \Delta 28$ $5^{\prime} \Delta 38,5^{\prime} \Delta 46$, and $5^{\prime} \Delta 53$ were also all assayed relative to $5^{\prime} \Delta 20$ and other constructs in several other experiments that are not shown, and these data were consistent with that shown. Data for 2R10 (no promoter) is shown only for experiment a. The deletions have been grouped into classes $(\mathrm{A}-\mathrm{D})$ as described in Results according to the relative level of maximum luciferase activity.

${ }^{a}$ Constructs $5^{\prime} \Delta 9$ and $5^{\prime} \Delta 12$ were each assayed relative to $5^{\prime} \Delta 20$ in a separate set of experiments. All constructs were assayed multiple times.

${ }^{b}$ For this experiment, the level of $5^{\prime} \Delta 21$ expression was $>10$-fold higher than in the other two experiments shown and in two additional experiments not shown. 


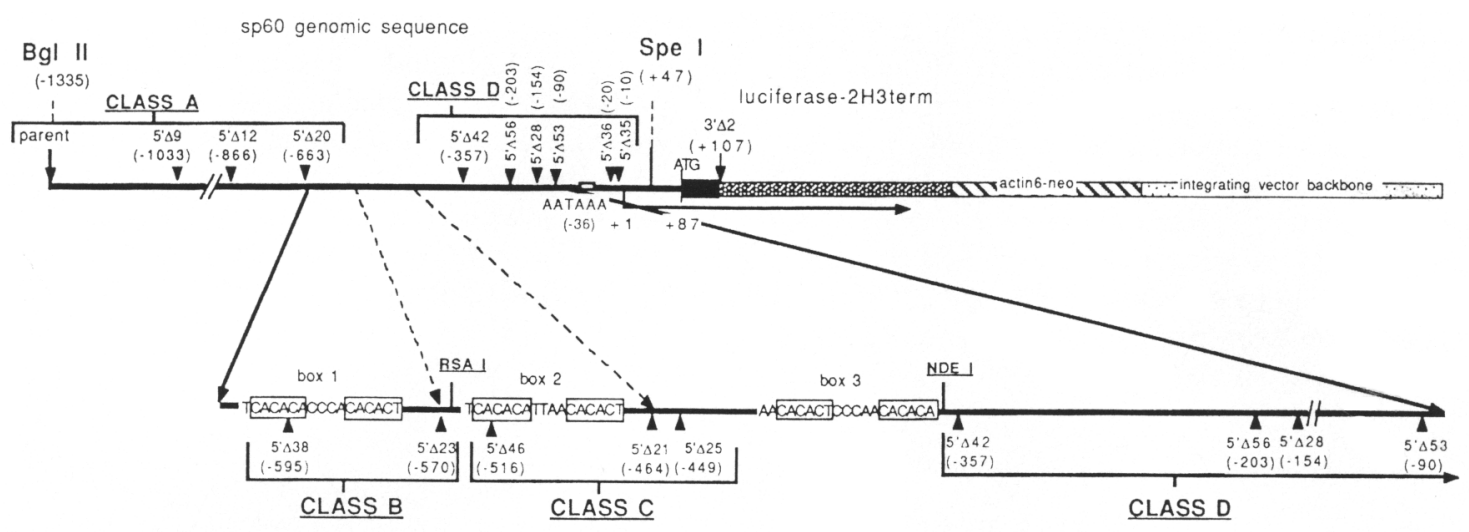

Figure 5. Deletion map of SP60 promoter region. The structure of the $5^{\prime}$-flanking region linked to luciferase is shown. The solid bar represents the $5^{\prime}$ region of the SP60 gene extending from the BglII site at position - 1313 bp shown in Fig. 1 to the ATG translation initiation codon. The BglII site and the SpeI site in the 5'-untranslated region (highlighted in Fig. 1), are shown in boldface type. The position of the $5^{\prime}$ deletions are labeled and marked by arrowheads. The numbers in parentheses represent the position of the deletion relative to the cap site. The position of the cap site is labeled by +1 , and the position of the putative TATA box is indicated. The region between -600 and $-50 \mathrm{bp}$ is expanded to show the sequences that are designated CAEs and labeled box 1 -box 3 (for further description, see Results). The exact position of 5' deletions lying within this region are shown, as are the positions of the unique RsaI and NdeI sites. Luciferase reporter gene analysis allows us to categorize these deletions into four classes (A-D) (see Table 1), and the grouping of each class of deletions is shown. The patterned bar represents other regions of the vector. The solid region indicates the SP60-coding region, the dark stippled region is the luciferase-coding region and a Dictyostelium gene terminator designated $2 \mathrm{H} 3$ (from the gene encoding SP70; see Crowley et al. 1985), the hatched region shows the position of the Act6-neo ${ }^{R}$ gene fusion conferring G418 resistance, and the lightly stippled region shows the vector backbone. A more detailed map of the transformation vector and details of its construction are given in Fig. 9.

$5^{\prime} \Delta 20$ in these deletions, the activity is developmentally regulated and increases 15 - to 25 -fold between starvation and $18 \mathrm{hr}$. Deletion $5^{\prime} \Delta 46$, which removes the first CA of CAE box 2, as well as 56 bp between $5^{\prime} \Delta 23$ and $5^{\prime} \Delta 46$, results in a 5- to 10 -fold reduction in expression at $18 \mathrm{hr}$ relative to the class $B$ deletion $5^{\prime} \Delta 23$.

Subsequent deletions that remove box 3 and surrounding sequence (class $\mathrm{D}$ ) result in a basal expression that does not show significant change during development. The expression level of these constructs in vegetative cells is approximately the same as that of $2 \mathrm{R} 10$ (promoterless construct). The specific activity of $2 \mathrm{R} 10$ is approximately constant through development.

RNA isolated from stable transformants expressing the 2IN, $5^{\prime} \Delta 20$, and $5^{\prime} \Delta 23$-luciferase constructs was used for a developmental RNA blot. The relative levels of SP60-luciferase RNA are consistent with the levels of luciferase activity in cells carrying the different deletion mutants (see Fig. 6A). Figure 6B shows that the $1 u$ ciferase probe does not hybridize to untransformed cells.

A series of internal deletions were also made using the unique RsaI and NdeI sites in the $5^{\prime}$-flanking sequence (see Materials and methods). An internal deletion of 76 bp between $-538(R s a)$ and $-466\left(5^{\prime} \Delta 21\right)$-construct 2liRsa-which removes the second CAE (box 2) and surrounding sequences, results in a level of expression similar to that of deletion $5^{\prime} \Delta 23$ [deletion of the first $\mathrm{CAE}$ (box 1) and surrounding sequences], as assayed by luciferase activity $\left(1.2 \times 10^{5}\right.$ for 2 liRsa; $1.5 \times 10^{5}$ for $5^{\prime} \Delta 23$; and $3.0 \times 10^{2}$ for $\left.5^{\prime} \Delta 21\right)$. These results suggest that the two regions between -664 and -571 and between -566 and -465 perform a common function. When a fragment lying between -664 and the NdeI site at $-383 \mathrm{bp}$, which contains all three CAEs, was placed on deletions at $-154\left(5^{\prime} \Delta 28\right)$ or $-90\left(5^{\prime} \Delta 53\right)$, no developmental induction of luciferase activity was observed (data not shown), indicating that sequences lying $3^{\prime}$ to the CAE-containing domains are also essential for expression.

\section{Regulation by cAMP}

Previously, we have shown that the endogenous SP60 mRNA is inducible by cAMP in slow-shake culture, using the 3-E2 cDNA probe (Mehdy et al. 1983). To determine whether the SP60-luciferase construct was so regulated, cells transformed with the $2 \mathrm{IN}-, 5^{\prime} \Delta 20-$, $5^{\prime} \Delta 23-, 5^{\prime} \Delta 21-$, and $5^{\prime} \Delta 42-$ luciferase fusion genes were washed free of nutrient medium and placed in slowshake culture in buffered salts. At $6.5 \mathrm{hr}$, one-half of the culture was given high, continuous levels of cAMP, whereas the other half was not. Cells were harvested at $16 \mathrm{hr}$, and luciferase activity was measured in extracts. As shown in Table 2, the + cAMP extracts had substantially higher luciferase activity ( $\sim 40$-fold) than the - cAMP cultures. As the regions containing CAEs and surrounding sequences are sequentially deleted, the levels of cAMP-inducible expression drop in parallel with the level of expression seen in multicellular development, suggesting that these regions are needed for both CAMP and developmental induction. Deletion of all three regions $\left(5^{\prime} \Delta 42\right)$ results in a loss of cAMP induction. There is some induction in the - cAMP cultures that is variable from culture to culture. This has also been seen when endogenous gene expression is assayed by RNA blots and is believed to be due to low levels of 

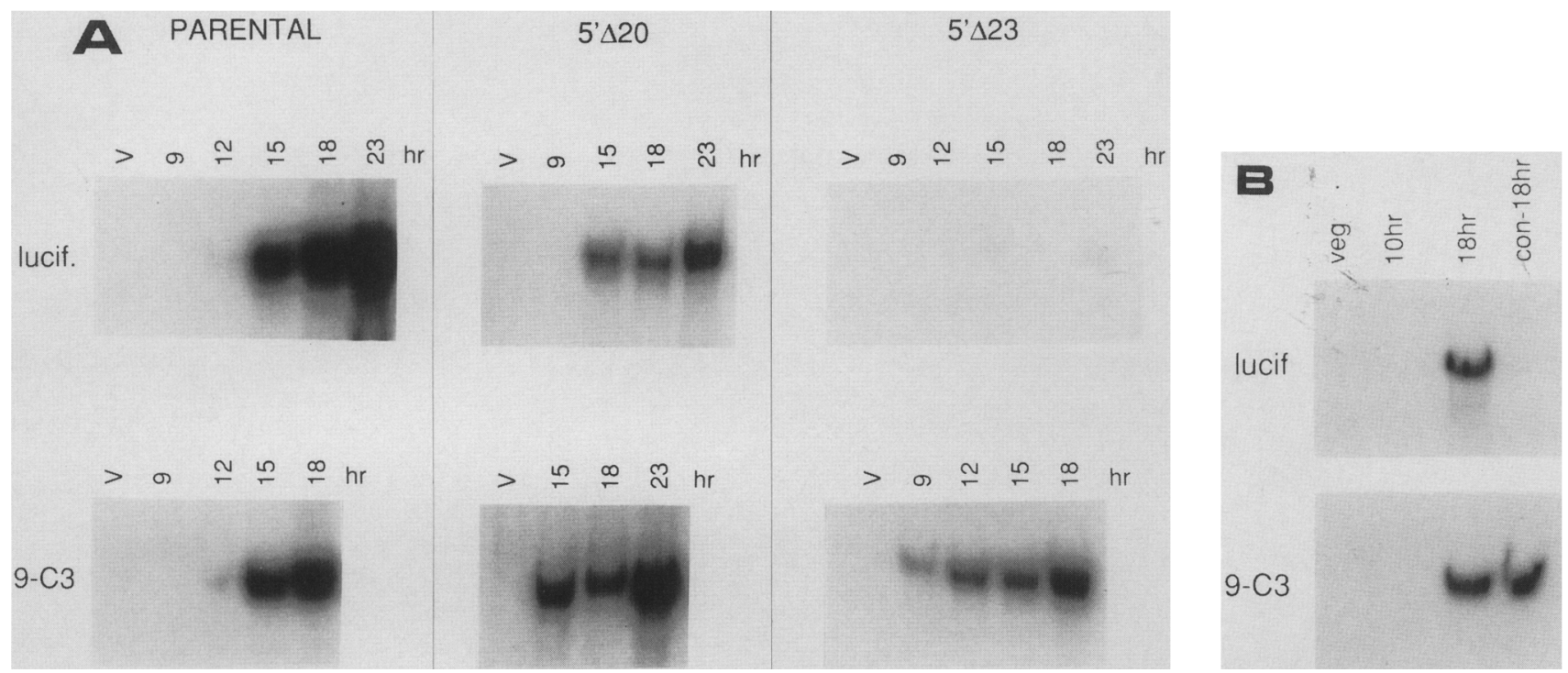

Figure 6. RNA blot hybridization of SP60-luciferase expression. (A) RNA was isolated from $2 \mathrm{IN}$ (parental), 5' $\Delta 20-$, and $5^{\prime} \Delta 23-1 u c i-$ ferase constructs at the times shown. RNA was size-fractionated, blotted, and hybridized with SP60 cDNA (9-C3) or luciferase (lucif.) probes. The RNA was from experiment c, shown in Table 1. The 18-hr lanes for $\Delta 20$ and $\Delta 23$ contain only one-half the RNA in the other lanes. (B) RNA was isolated from vegetative cells (veg) and 10 and $18 \mathrm{hr}$ of multicellular development from $5^{\prime} \Delta 20 l u c$ transformants and also from control, untransformed cells at $18 \mathrm{hr}$ (con-18hr). These were blotted and probed with either a luciferase-coding region (lucif) or SP60 cDNA (9-C3).

cAMP produced in the aggregates that form this culture system (Mehdy et al. 1983; Mehdy and Firtel 1985).

\section{Spatial expression of fusion gene products}

The firefly luciferase reporter gene provides an extremely sensitive and quantitative expression assay, and the above data indicate that the SP60-luciferase fusion gene shows the proper temporal pattern of expression and is inducible by cAMP. However, cytological localization of the fusion gene product in aggregates is not possible when using available antibodies and fixing procedures that work well for Dictyostelium (Gomer et al. 1986a, Gomer 1987a,b). To determine whether the fusion gene products are preferentially expressed in prespore cells, we have made $S P 60-1 a c Z$ gene fusions (SP60-lacZ). The parental construct $\left(5^{\prime} \Delta 20 \beta\right.$-gal) contains the $5^{\prime} \Delta 20$ upstream region, which is sufficient for complete temporal and cAMP regulation (see above), and

Table 2. Induction by $c A M P$

\begin{tabular}{|c|c|c|}
\hline & \multicolumn{2}{|c|}{ 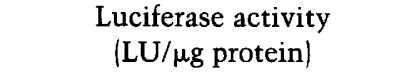 } \\
\hline & -cAMP & + cAMP \\
\hline Parent & $1.9 \times 10^{3}$ & $3.1 \times 10^{5}$ \\
\hline $5^{\prime} \Delta 20$ & $2.0 \times 10^{3}$ & $4.8 \times 10^{4}$ \\
\hline $5^{\prime} \Delta 23$ & $3.6 \times 10^{2}$ & $1.4 \times 10^{4}$ \\
\hline $5^{\prime} \Delta 21$ & 18 & $3.6 \times 10^{2}$ \\
\hline $5^{\prime} \Delta 42$ & 3.3 & 5.6 \\
\hline
\end{tabular}

Vegetative cells were harvested, washed, and resuspended in MES-PDF and shaken at $130 \mathrm{rpm}$ for $6.5 \mathrm{hr}$. cAMP was added to $300 \mu \mathrm{M}$ in one-half of the suspensions and readded every $3-4 \mathrm{hr}$ to $100 \mu \mathrm{M}$. Cells were harvested at $16 \mathrm{hr}$ and assayed. the $S P 60$-coding sequence to codon 7 fused in-frame to the Escherichia coli lacZ gene at codon 9 in the same vector background as the SP60-luciferase gene fusions (see Fig. 9). The position within the SP60 sequence used in the fusion is identical to that used for the luciferase gene fusion. Stable $5^{\prime} \Delta 20-l a c Z$ transformants were plated for development and stained for $\beta$-gal activity (see Materials and methods). Figure 7 (I and II) shows the staining pattern of slugs and early culminants of these transformants. Control, untransformed cells at the same developmental stages are shown in Figure 7I and do not stain. As can be seen, the posterior $85 \%$ of migrating slugs and culminants (i.e., the entire prespore zone) expressing the $5^{\prime} \Delta 20-1 a c Z$ fusion construct stains uniformly and very strongly, whereas the anterior remains unstained except for several random cells (see Discussion). Fruiting bodies show preferential staining in the sorocarp containing the spore mass. The pattern of staining seen with this construct is indistinguishable from that seen by immunofluorescence with an antibody that recognizes a common post-translational modification of the spore coat proteins SP60, SP70, and SP96 and with an anti-SP70 antibody made against a fusion protein expressed in E. coli (Takeuchi 1963; Gomer et al. 1986a). This is also consistent with earlier two-dimensional gel results examining the expression of SP60 in dissected anterior and posterior portions of migrating slugs and mature spores (Devine et al. 1983; Morrissey et al. 1984). A similar pattern is seen for the prespore gene $D 19$, which encodes a protein found in the slime sheath surrounding the migrating slug, through the use of monoclonal antibodies and $l a c Z$ fusion constructs (Krefft et al. 1984; Early and Williams 1988; Early et al. 1988; Dingermann et al. 1990). Untransformed cells (see 

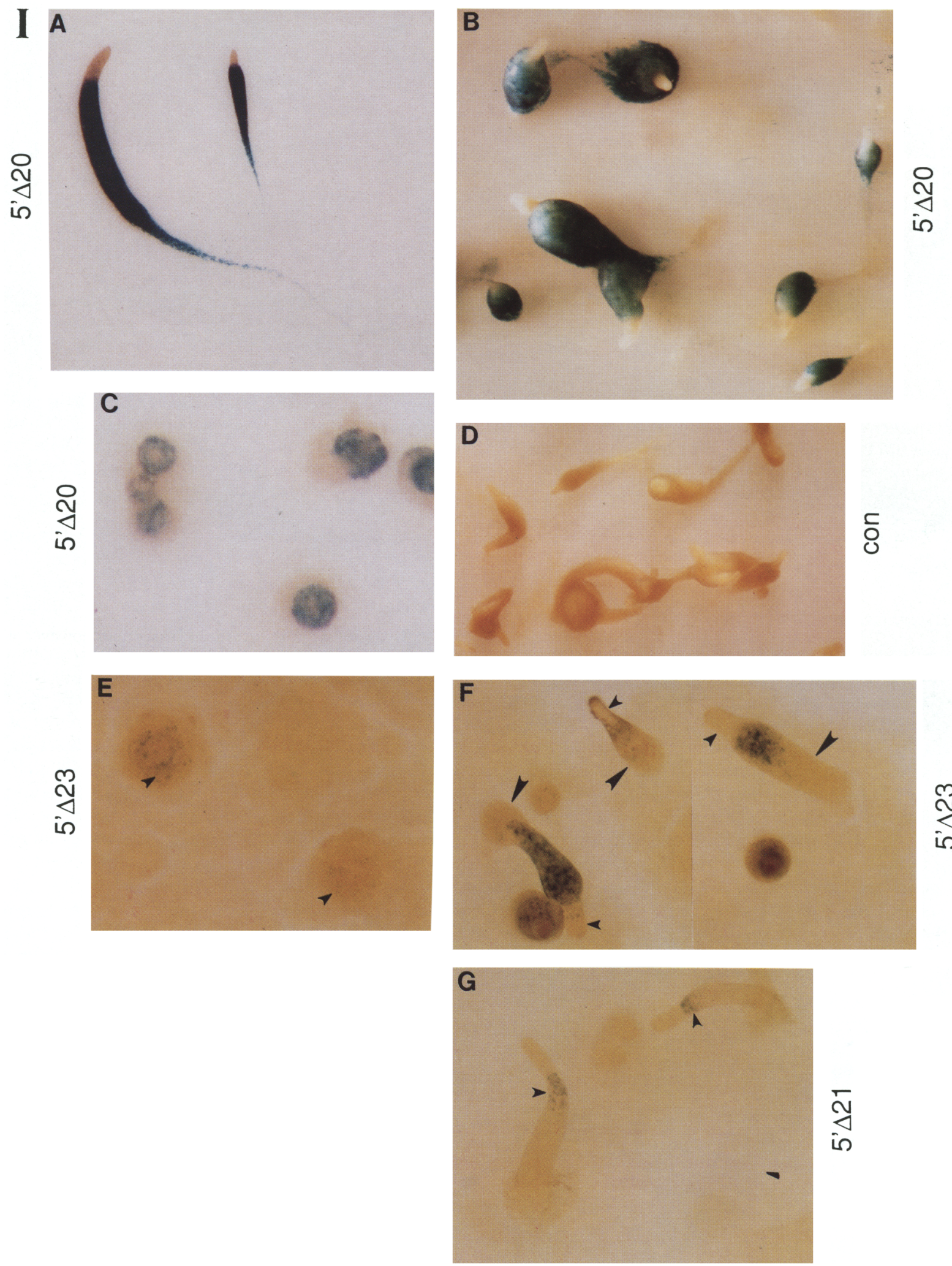

Figure 7. (Continued on facing page.)
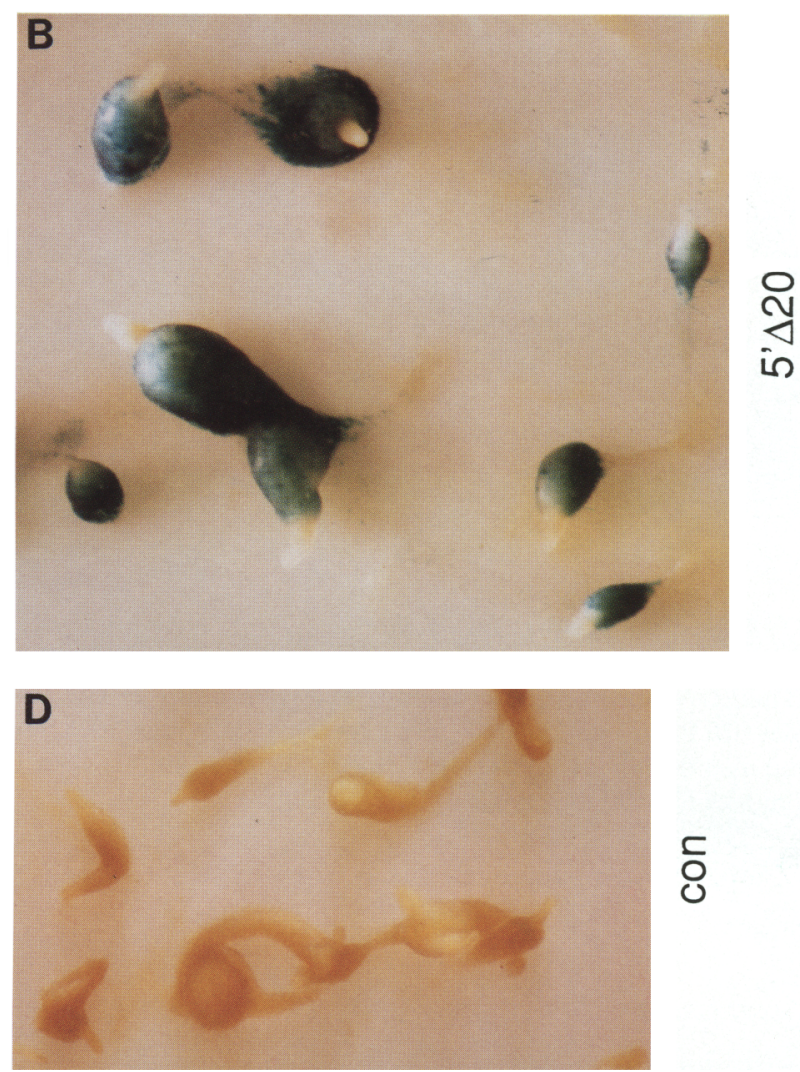

$\underset{\text { in }}{\stackrel{M}{0}}$
ע

in 


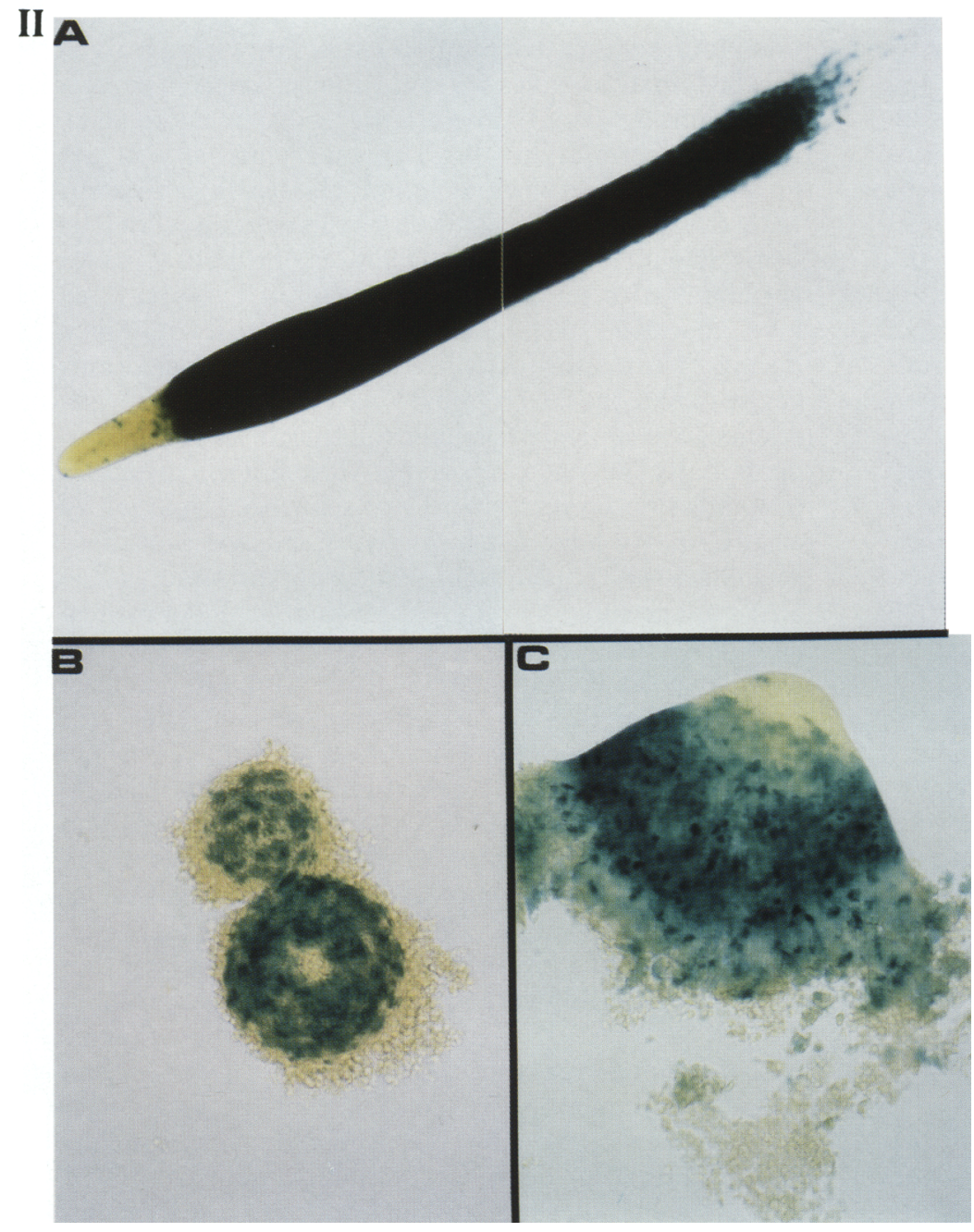

Figure 7. Cytological staining of SP60-lacZ constructs. Individual panels are labeled. Staining was performed as described in Materials and methods. $(I)$ Photographs were taken through a dissecting microscope. All aggregates are stained for approximately the same amount of time $(5 \mathrm{hr}) .\langle A| 5^{\prime} \Delta 20$ (complete promoter|. Migrating slugs. The unstained anterior prestalk zone is visible. (B) $5^{\prime} \Delta 20$. Early culminants and fruiting bodies. $\left\{C \mid 5^{\prime} \Delta 20,9-\right.$ to 10 -hr early aggregates. A ring of stained cells is visible. The very center and skirt of cells around ring are unstained (see text $).(D)$ Control aggregates, slugs, early culminants (untransformed cells). No staining. (E) $5^{\prime} \Delta 23$ (promoter lacking first CAE and adjacent sequence), 9- to 10-hr early aggregates. Stained cells (small arrow) create a circular pattern around the unstained center. (F) $5^{\prime} \Delta 23$. Slugs and early culminants. The tip (small arrow) and posterior prespore zone (larger arrow) are unstained. There is a gradient of stain in the anterior of the prespore zone. $(G) 5^{\prime} \Delta 21$ (lacking first two CAEs). Standing slugs. Staining is restricted to the anterior of the prespore zone (small arrow). $\{I I)$ Photographs were taken through a compound microscope of slug and aggregates dissected off a Millipore filter and placed on a glass slide. (A) A migrating slug. (B) A view of an aggregation center at the early to mid-aggregation stage showing a ring of stained cells. The majority of the aggregation streams still entering the aggregate were lost in the dissection; however, a skirt of unstained cells is seen at the periphery. The very center of the aggregate shows no staining. $(C)$ A side view of a slightly later stage (tipped aggregate). Note that some cells stain more intensely.

Fig. 7I) and cells transformed with a lacZ construct lacking a promoter (not shown) show no detectable staining.

We have also examined the level and spatial pattern of expression using $\operatorname{lac} Z$ fusions with $5^{\prime} \Delta 23,5^{\prime} \Delta 21$, and $5^{\prime} \Delta 42$ promoter regions. $5^{\prime} \Delta 23$ and $5^{\prime} \Delta 21$, which lack the first $\left(5^{\prime}\right.$-most) and second regulatory domains, respectively, showed sequentially reduced expression relative to that observed with the $5^{\prime} \Delta 20$ construct, as might be expected from results with the luciferase assay (Fig. $7 \mathrm{I}$; cells were all stained for $\sim 5 \mathrm{hr}$ ). Significant staining can be seen with $5^{\prime} \Delta 20-1 a c Z$ in $5-10 \mathrm{~min}$. Little staining can be seen with $5^{\prime} \Delta 23-1 a c Z$ in the first hour. This suggests that even within the cells that express $\beta$-gal activity, the promoter activity of the $5^{\prime} \Delta 23$ construct is significantly reduced from that of $5^{\prime} \Delta 20$. Moreover, $5^{\prime} \Delta 21-1 a c Z$ stains more slowly than $5^{\prime} \Delta 23$. In addition, with the subsequent deletions, a decreasing gradient of expression from the anterior to the posterior of the prespore zone is observed, as the cells that stain became progressively restricted to the anterior of this region. In slugs and early culminants from the $5^{\prime} \Delta 23-$ lacZ-expressing cells, staining is observed in the anterior one-third to one-half of the prespore zone, with a gradient of decreasing staining toward the posterior. In 5' $21-$ lacZ transformants, staining was restricted to a collar of prespore cells at the interface with the prestalk zone. Transformants carrying $5^{\prime} \Delta 42-, 5^{\prime} \Delta 28-$, and $5^{\prime} \Delta 53-1 a c Z$ gene fusions showed no detectable staining (data not shown). These data are in agreement with the results from similar constructs with luciferase as the reporter gene (see Table 1). It is also worth noting that with both $5^{\prime} \Delta 20-1 a c Z$ and $5^{\prime} \Delta 23-1 a c Z$ constructs, some cells stain substantially stronger than others during the tipped aggregate stage (Fig. 7IIC) and in early culminants (data not shown).

The sensitivity of the luciferase assay has shown that prespore gene expression begins to be induced at the time of aggregate formation, earlier than previously observed from less sensitive RNA blot data with total RNA. Therefore, we examined the spatial distribution of expression at the early and mid to late stages of aggregation. Figure 7, I and II, includes photographs of the lacZ pattern of expression at these earlier stages. When viewing the aggregate from above, one sees staining in the body of the aggregate, except in the very center. At 
this point in development, an estimated $20 \%$ of the cells are staining. This nonstaining central region eventually forms the anterior tip region of the migrating slug and the prestalk zone, which does not express $S P 60-$ lacZ fusions (Fig. 7I). The skirt around the aggregate contains the streams of cells entering the aggregate. As can be seen, the cells within the skirt show no detectable $\beta$-gal staining. Therefore, even in early aggregation, only the cells that will become localized in the prespore zone are detectably expressing the fusion gene product. Within an hour of the stage shown here, the formation of the multicellular aggregate will be complete and a pronounced tip will have formed. Eventually $80-85 \%$ will express the $5^{\prime} \Delta 20-1 a c Z$ fusion protein. Aggregates of $5^{\prime} \Delta 23-$ lacZ transformants also show slight staining of a ring of cells in the same region as is observed for the stronger $5^{\prime} \Delta 20$ construct. The $5^{\prime} \Delta 21$ construct shows no detectable staining at this point (not shown), presumably because of the weakness of the promoter.

Figure 7II shows a side view of aggregates at mid (Fig. 7IIB) and late (Fig. 7IIC) aggregation that have been dissected off the Millipore filters. As can be seen, staining is preferentially localized to a ring of cells within the aggregate mass, suggesting that expression of this gene may be controlled, in part, by spatial determinants. Some of the cells do show more intense staining. This pattern demonstrates that many of the cells that stain positively are already localized at this earlier stage.

\section{Discussion}

We cloned the gene encoding the spore coat protein SP60 and analyzed the sequences required for expression of the gene. Using two different SP60-reporter gene fusions, we show that the $5^{\prime}$-flanking sequences contain all of the necessary sequence for proper temporal, cAMP, and spatial expression of the fusion gene within the developing aggregate as compared to the endogenous gene. These results are consistent with the cytological localization of the $S P 70$ gene product from immunofluorescence studies by using an antibody made against an SP70 fusion protein expressed in $E$. coli. They are also consistent with the results of Takeuchi and co-workers, who used antibodies against a carbohydrate moiety common to prespore proteins (Takeuchi 1963; Tasaka et al. 1983; Takemoto et al. 1985; Gomer et al. 1986a). The localized developmental pattern of SP60 expression reveals the initial patterning of prespore cells and is consistent with the involvement of spatial determinants in this process and with the results of Krefft et al. (1984) for the D19 gene product.

When a series of $5^{\prime}$-deletion mutations were analyzed, two general patterns were observed. First, major decreases in the level of expression were observed that correlated with sequential deletion of the three CAE boxes and surrounding sequences. The level of expression, as assayed by luciferase activity, drops precipitously with each CAE and surrounding sequence deletion. However, as the $\beta$-gal staining indicates, the decrease is not equal across all cells within the prespore zone. Thus, comparison of the absolute levels of luciferase specific activity for the different deletion classes does not give an accurate picture of relative promoter strength within a given cell but, instead, gives an indication of relative expression levels as averaged across the entire prespore zone. However, the varying $\beta$-gal staining intensity of expressing cells between deletion classes is consistent with the quantitative analysis of the deletion series by using the luciferase assay. Deletion of all three boxes correlates with the loss of all expression, except a basal level that is $\sim 10^{5}$-fold below that normally observed during culmination. Analysis of the internal deletions suggests that the two 5 '-most CAEs and surrounding sequences are equivalent in controlling the level of developmentally induced expression. Although the decreases in expression correlate with the sequential deletion of each CAE, we have not formally established that these sequences or the AT-rich sequences surrounding the CAEs are specifically required for high levels of expression.

Because the deletions are $5^{\prime}$ to the cap site, we infer that the differences in luciferase expression reflect differences in the rate of transcriptional activity. This is in agreement with developmental changes in the endogenous and fusion gene mRNA levels and nuclear run-on studies of the endogenous SP60 gene (R.A. Firtel, unpubl.). The sequence homology between the CAEs is evident and suggests that they may bind a transcription factor required for expression of this and possibly other coordinately regulated genes. Another prespore-specific protein is encoded by a gene containing homologous CAEs in its upstream regulatory region (J.A. Powell and R.A. Firtel, unpubl.). It is possible that the CAE boxes represent a prespore cell-type-specific element or an element required for cAMP regulation. Moreover, this sequence is homologous to one from $D G 17$, which has been shown to confer cAMP and temporal regulation to a heterologous gene (Hjorth et al. 1990). Although the three CAEs are quite homologous, there are nucleotide sequence differences, the significance of which is not presently known. Analysis of the regions required for expression of the DIF-inducible, prestalk-specific gene (st63) shows a number of GC-rich sequences, none of which looks similar to the CAEs of SP60 (J. Williams, pers. comm.). The $5^{\prime}$-flanking region of the cAMP-inducible cyclic nucleotide phosphodiesterase gene contains several CA/GT-rich regions, but their structures are different from those in SP60, and the function of these sequences or surrounding sequences in regulating the expression of this gene is not known (Podgorski et al. 19891.

Clearly, sequences more proximal to the cap site than the CAE-containing domains are also required for proper expression because the region from -663 to the NdeI site at -383 , which contains all three CAE-containing domains, does not rescue function when fused to $5^{\prime} \Delta 53$ $(-90)$ or $5^{\prime} \Delta 28(-154)$. Therefore, the region downstream of the NdeI site also contains essential cis-acting elements. Construct $5^{\prime} \Delta 42$ is missing all three CAEs and their surrounding sequences, but very little of the proximal domains. When the 80 -bp region containing essen- 
tial cis-acting elements from the cAMP-induced prestalk gene pst-cath (Datta and Firtel 1988; Hjorth et al. 1989) is added to this deletion, no developmental regulation is observed (L. Haberstroh and R.A. Firtel, unpubl.). Thus, it is possible that many elements specifying patterns of developmental regulation in Dictyostelium are promoter-specific.

Deletions between the upstream BglII site and the $5^{\prime} \Delta 20$ deletion result in a gradual three- to fivefold decline in the level of expression, both in vegetative cells and at $18 \mathrm{hr}$ of development. The expression in vegetative cells is extremely low $\left(>10^{4}\right.$-fold lower) relative to that observed at $18 \mathrm{hr}$. Luciferase appears to be very stable in Dictyostelium cells /when the enzyme is expressed from an actin promoter that is turned off early in development, it is present at $18 \mathrm{hr}$, and the low level of activity that is present in growing cells accumulates over the entire vegetative cell cycle, which is $\sim 10 \mathrm{hr}$. In contrast, developing cells show an $\sim 10^{4}$-fold increase between 10 and $18 \mathrm{hr}$ of development. Because no SP60luciferase RNA can be detected in vegetative cells by any assay we have tried, we cannot tell whether the luciferase is being expressed from the same or a different promoter used for developmental expression. The sensitivity of the luciferase assay is sufficiently high that random, nonspecific initiations from within the upstream region could be detected using this assay. The level of vegetative expression correlates with the length of the $5^{\prime}$-flanking region rather than any specific sequence.

\section{Evidence for a gradient regulating SP60 expression within the prespore zone}

The SP60-lacZ fusion protein is almost exclusively expressed in the prespore cells. In some aggregates, several cells are seen to stain in the anterior region or, in some cases, in the maturing stalk when mid-stage culminants are examined. There is no obvious pattern to these cells, and they represent $\leqslant 1 \%$ of the cells in this region; most slugs and culminants show staining only within the posterior prespore zone. Staining of early aggregates, when cells are still moving into the aggregate, shows a novel pattern, indicating that the cells expressing SP60-1acZ are localized at this early stage. Because Sp60- $\beta$-galstaining cells represent $\geqslant 80 \%$ of the cells several hours later at the slug stage, many of the cells that are still moving into the aggregate must still be recruited into the prespore zone, possibly as they enter the ring of cells described in Figure 7. This suggests that spatial information may be essential in forming the prespore zone. Dingermann et al. (1990) have shown that lacZ expression driven by an actin promoter takes place in all cells during growth and early development, and slugs show uniform staining from the anterior to the posterior. Moreover, a lacZ fusion with a prestalk gene (Dd-ras) shows strong preferential staining in the anterior tip of the prestalk zone in migrating slugs (R.K. Esch and R.A. Firtel, in prep.), indicating that our observations are not the result of an artifact of the staining procedure. We also note that for $5^{\prime} \Delta 20 S P 60-1 a c Z$ transformants, the entire posterior $85 \%$ of migrating slugs stains, including the tail ends. One may have expected that the very posterior, which is believed to produce basal cells that express anterior markers, might not stain. However, recent results show that basal cells of the tipped aggregate that express the DIF-inducible genes st56 and st63 are sloughed off when slugs form and then begin to migrate (Jermyn et al. 1989; J. Williams, pers. comm.). This is also seen for the spatial expression of Dd-ras-lacZ (R.K. Esch and R.A. Firtel, in prep.) and thus accounts for a lack of non-SP60-lacZ-expressing cells in the posterior of migrating slugs.

A novel finding is that sequential deletions result not only in a reduced maximal level of expression but also in restricted spatial expression. Although a gradient of $\beta$-gal staining is not observed with the full $S P 60$ promoter-lacZ construct $\left(5^{\prime} \Delta 20-l a c Z\right)$, even in slugs stained for a short period of time, sequential deletions within the distal regulatory region do result in such a gradient. A promoter deletion with only one CAE-containing region shows detectable expression only at the very anterior of the prespore zone. A promoter carrying two boxes and surrounding sequences shows expression in this collar region and in a posteriorly decreasing gradient in the anterior $\sim 50 \%$ of the prespore domain. Deletion analysis suggested that at least two of the three CAE-containing $5^{\prime}$ domains are functionally equivalent elements. The $\beta$-gal staining pattern of the $5^{\prime}$ deletion constructs therefore appears to have unmasked the presence of a spatial gradient within the prespore zone that becomes evident with $1 a c Z$ expression from sequentially weaker promoters (see Fig. 8). This could be a gradient of an essential transcription factor, possibly one recognizing the CAE. Moreover, the effects of the CAE and surrounding sequences are multiplicative, which is in agreement with the effect of sequential deletions on luciferase levels. This would be similar to the proposed mechanism by which bicoid-responsive elements in the hunchback regulatory region have been suggested to recognize a bicoid gradient to establish a discrete zone of hunchback transcription (Driever et al. 1989; Struhl et al. 1989|. The observation that a decreasing number of distal elements results in a decrease in the proportion of the prespore zone that stains suggests that the CAEs and surrounding regions contain sequences that may be recognized by transcription factors that work cooperatively for the expression of SP60. In such a scenario, active transcription factors would be present across the prespore zone of the slug in a gradient from the anterior (higher concentration) to posterior (lower concentration) within the cells. In the bicoid/hunchback example, the syncytium allows an internal gradient of bicoid to arise across the entire organism. In contrast, Dictyostelium is composed of individual cells and would require transduction of some external signal across cells membranes into an internal, active transcription factor gradient across the organism. Such an active transcription factor gradient could arise in response to an anterior-to-posterior gradient of a positive morphogen (e.g., cAMP), 
cAMP receptors, or intracellular effectors or to an inverse gradient of an inhibiting morphogen such as DIF. DIF, known to inhibit the transcription of the prespore gene $D 19$ (Early and Williams 1988) and induce a specific class of prestalk genes (Williams et al. 1987), is paradoxically localized primarily in the posterior of the slug (Brookman et al. 1987). Whether DIF is present in a gradient within the posterior region is not known.

We are still left with the question of how the two zones are established and what determines the very sharp division between the two. Because SP60-lacZ expression can be detected first in a marginal zone within the early aggregate, the information necessary to activate expression in specific cells must be established by this point. Previously, several laboratories demonstrated that the propensity of single cells to differentiate into prespore or prestalk is based on the position of the cell in the cell cycle at the time of initiation of development (starvation) (MacDonald and Durston 1984; Weijer et al. 1984; MacWilliams et al. 1985; Gomer and Firtel 1987). How this cell cycle is manifested in the spatial patterning of prestalk and prespore cells is not known. Perhaps we are dealing with a two-factor differentiation scheme: (1) cell cycle position at starvation (some "organizing" cells), and (2) position within the forming aggregate in which cells that are uncommitted at the time of starvation are induced by their position within the aggregate and the relative concentrations of various morphogens.

\section{Materials and methods}

\section{General methods}

Axenically grown $\mathrm{KAx}-3$ cells were used in these studies (Mehdy et al. 1983).

Vegetative Dictyostelium cells were transformed by electroporation, and stable transformants were selected at a G418 concentration of $10 \mu \mathrm{g} / \mathrm{ml}$, as described previously (Howard et al. 1988; Dynes and Firtel 1990|. Whole transformed populations were utilized for the analyses. Transformed populations were maintained as logarithmically dividing cells.

\section{RNA and DNA analysis}

RNA was isolated from cells and size-fractionated on denaturing gels, blotted, and hybridized with the appropriate clones, as described previously (Mann and Firtel 1987). DNA was isolated from transformants and from untransformed large cultures of Dictyostelium, as described previously (Datta and Firtel 1987). Sl mapping of the $5^{\prime}$ ends was performed with single-stranded DNA probes labeled with $\left[{ }^{32} \mathrm{P}\right] \mathrm{dCTP}$ and derived from M13 phage DNA, by using the standard sequence primer and the Klenow fragment of DNA polymerase I (Berk and Sharp 1977; Maniatis et al. 1982; J.A. Powell and R.A. Firtel, in prep.). After polymerization, the product was digested with HindIII. This linearizes the M13 vector and produces a full-length probe fragment. In addition, partial-length fragments from the probe region plus fragments complementary to the M13 backbone are also produced. The products are denatured, and the full-length single-stranded probe is isolated on urea-containing partial denaturing sequencing gels.

The probe for mapping the endogenous SP60 transcript extended from the $H p h I$ site at $+146\left(5^{\prime}\right.$ end of probe) to the $5^{\prime} \Delta 20$ HindIII site $(-663)$ (see Fig. 3A, top and bottom). RNA from 18-hr untransformed cells was used. To map the SP60-luciferase transcript, a probe from the $\mathrm{XbaI}$ site $(+99)$ of luciferase ( $5^{\prime}$ end to the HindIII site of $5^{\prime} \Delta 28$ at -154 and RNA from 18 -hr 5' $\triangle 20 S P 60$-luciferase transformed cells were used (see Fig. 3B, top and bottom). Because the SP60-lacZ and SP6O-luciferase fusion vectors are identical upstream from the SpeI site, which lies within the $5^{\prime}$-untranslated sequence and thus downstream from the mapped endogenous cap site, the cap site for the SP60-lacZ fusions was not mapped.

The polarity of transcription was determined with strandspecific RNA probes. The 3-E2 cDNA was cloned into the PstI site of pSP73 (Promega) and linearized at either the BglII site (for a T7 RNA polymerase-derived probe) or the Xhol site (for an SP6 RNA polymerase-derived probe). The linearized DNAs were transcribed by using T7 and SP6 polymerase (Promega), respectively, with a $\left.\alpha{ }^{32} \mathrm{P}\right] \mathrm{CTP}$, according to the manufacturer's directions. These were hybridized separately to blots containing RNA from 18 -hr cells. The hybridization pattern was then related to the DNA sequence of the cDNA in SP73.

\section{DNA sequencing}

Dideoxy DNA sequencing with modified T7 DNA polymerase

deletion
$\Delta 20$
$\Delta 23$
$\Delta 21$
$\Delta 42$

Figure 8. Model for prespore zone gradient. (Top) Cartoon of the SP60 promoter-lacZ staining response (intensity and localization of expression) and cAMP and developmental response for the various promoter constructs. (Bottom) Model showing two possible gradients within the prespore zone to explain $S P 60$ promoter-lacZ responses. Positive gradient could be transcription factors or parts of the cAMP receptor/intracellular signaling pathway. Negative gradient could be DIF, adenosine, or some other metabolite/morphogen.

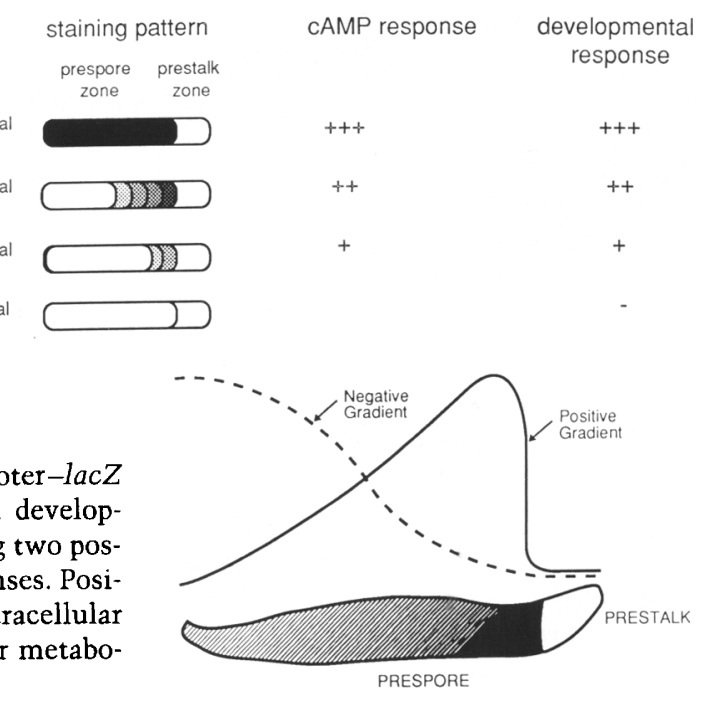


was performed on subclones, on all $5^{\prime}$ deletions, and on the 3-E2 cDNA.

\section{Cloning of SP60}

SP60 genomic clones were isolated by screening two genomic libraries constructed by use of mapping data for Dictyostelium genomic DNA digested with various restriction enzymes and hybridized with 3-E2 and 9-C3 cDNA inserts. One library contained a BglII limit digest of Dictyostelium DNA cloned into the BamHI site of pAT153. The second library contained Dictyostelium genomic DNA, double-digested with $P_{s t \mathrm{I}}$ and $\mathrm{XbaI}$ and inserted into an $\mathrm{XbaI}$ limit/PstI partial digest of a modified pAT153 plasmid vector. This modified pAT153, designated pAT153L, contained the polylinker from pSP73 (Promega Biotec) inserted between the EcoRI site and the SalI site of pAT153. The insertion of the polylinker was accomplished by ligating a blunt-ended $B g$ III site on one end of the polylinker into a blunt-ended EcoRI site from pAT153 and the XhoI site at the other end of the polylinker into the Sall site of vector sequences. The cloning deleted the unique EcoRI, HindIII, ClaI, BamHI, EcoRV, SphI, and SalI sites and $\sim 675$ bp of the vector, including the sequences required for tetracycline resistance. These sites, however, as well as other unique restriction sites, are present in the polylinker. Because of the cloning protocol, the BgIII and XhoI sites in the polylinker were lost in the cloning. The vector has two PstI sites, one in the $A \mathrm{mp}^{\mathrm{R}}$ gene and one in the polylinker. The unmodified pAT153 vector had previously been used successfully to construct Dictyostelium genomic libraries (J. Williams, pers. comm.). In our hands, both pAT153 and pAT153L work substantially better for cloning Dictyostelium genomic sequences than pUC-based vectors. Unusually AT-rich Dictyostelium sequences that are relatively unstable in other vectors (unpubl.) can be cloned in pAT153, possibly because of this vector's lower copy number in $E$. coli.

cDNA inserts were gel-purified two times from the 9-C3 and 3-E2 cDNA clones, labeled by nick-translation or random primer extension, and used to screen high-density colony blots of each library. Two clones carrying an $\sim 7-\mathrm{kb} B g l I I$ fragment, including the $3^{\prime}$ end of $S P 60$, were isolated out of $\sim 5 \times 10^{4} \mathrm{col}-$ onies of the BglII library screened with the 9-C3 cDNA as a probe. Four clones carrying a $4.5-\mathrm{kb} X b a \mathrm{I}-P s t \mathrm{I}$ fragment containing the $5^{\prime}$ end of SP 60 were isolated out of $\sim 5 \times 10^{4}$ colonies screened with the $3-\mathrm{E} 2 \mathrm{cDNA}$ as a probe. Clones were mapped using standard techniques, and subclones were sequenced from double-stranded DNA subcloned into $\mathrm{pSP} 73$ with modified T7 DNA polymerase (Promega or U.S. Biochemical).

\section{Deletion analysis}

Deletions $\left(3^{\prime}\right)$ were made of the $\sim 2$-kb BglII $5^{\prime}$ fragment from the SP60 gene with ExoIII; they were then HindIII linkercapped, cloned into pSP73, and sequenced. A 3' deletion that ended between codons 7 and 8 was capped with a HindIII linker and used as starting material for making the luciferase and lacZ gene fusions. This was ligated to a HindIII site at the $5^{\prime}$ end of the firefly luciferase gene that had been used previously to construct a Dictyostelium Actin 15-luciferase gene fusion vector designated VIILuc (Howard et al. 1988). Because the reading frames of the two genes were not in-frame, the fusion was linearized at the HindIII site and then filled in and religated to give the appropriate reading frame. This was confirmed by DNA sequence analysis.

To construct $5^{\prime}$ deletions, the restriction fragment extending from the $B g I I I$ site at nucleotide -1335 in Figure 1 through an $X b a I$ site at nucleotide +99 in the luciferase gene was subcloned into pSP73 and used for making ExoIII unidirectional deletions starting at the BgIII site. Deletions were capped with a
HindIII linker. The full-length and individual SP60 promoter constructs were then cloned into the vector Cath-Luc13 (Howard et al. 1988) (see Fig. 8) in which the pst-cath promoter had been deleted. Cath-Luc13 was originally derived from VIILuc (Howard et al. 1988). Deletion end points were determined by DNA sequencing.

The $l a c Z$ construct was made by isolating the $1 a c Z$ gene from $\mathrm{pC} 41$ lacZ and pC4AUGlacZ (a gift from $\mathrm{C}$. Zuker), filling in the $5^{\prime}$ overhang of a BamHI site, adding a HindIII linker (10-mer), and linking this in-frame to the $S P 603^{\prime} \Delta 2$ deletion used to construct the luciferase fusions. This was then cloned into the same vector backbone as that used for the luciferase gene (see Fig. 9).

Luciferase and lacZ fusions carrying different promoter deletions were made by exchanging the restriction fragment containing the promoter from the $5^{\prime}$ unique $B g I I I$ and SpeI sites in the 5 '-untranslated sequence of SP60.

\section{Development and CAMP assays}

For multicellular development, axenically grown log-phase vegetative cells were harvested by centrifugation, washed, and plated on Whatman No. 50 filters in (MES-PDF) buffered salts, as described previously. Development was followed visually under a dissecting microscope. Cells were harvested at the loose aggregate $(9-10 \mathrm{hr})$ and early culminant stages $(\sim 18 \mathrm{hr})$.

For developmental RNA blots, RNA was extracted and sized on denaturing gels, blotted to membrane filters, and probed with nick-translated or random-primed probed, as described previously (Mann and Firtel 1987). For the luciferase assays, cells were harvested in glycyl-glycine buffer with protease inhibitors and quick-frozen in a dry ice-ethanol bath, as described previously (Howard et al. 1988).

Slow-shake culture was done as described previously (Mehdy et al. 1983; Mehdy and Firtel 1985). Briefly, vegetative cells were harvested and washed as described above and resuspended in MES-PDF at $5 \times 10^{6} \mathrm{cells} / \mathrm{ml}$. Cells were shaken at $130 \mathrm{rpm}$ (10 ml/125-ml Erlenmeyer screw-cap flask) for $6.5 \mathrm{hr}$. cAMP was added to one-half of the cultures to $300 \mu \mathrm{M}$. cAMP was readded every $3-4 \mathrm{hr}$ to a concentration of $100 \mu \mathrm{M}$. Cells were harvested at $16 \mathrm{hr}$.

\section{Cytological staining}

Dictyostelium cells were plated for development as described above, except that they were plated on white Millipore filters. At appropriate times, aggregates were stained for $\beta$-gal activity using a modification of the procedure of Dingermann et al. (1990). Cells were fixed for $15-45 \mathrm{~min}$ in $0.5 \%$ glutaraldehyde in $Z^{\prime}$ buffer, washed in $Z^{\prime}$ buffer, and stained with X-gal (BRL) in the presence of potassium ferrocyanide and potassium ferricyanide at $37^{\circ} \mathrm{C}$ (Dingermann et al. 1990). Extended staining (24 hr at $37^{\circ} \mathrm{C}$ ) showed a very slight blue tinge in untransformed aggregates, presumably due to an endogenous Dictyostelium $\beta$-gal activity. This activity is minimal at $\mathrm{pH} 6.9$, used in the staining in these studies, and was not reduced by the presence of $2 \mathrm{mM}$ EGTA. The dark blue color is seen in the transformants of 5' $\Delta 20 S P 60-$ lacZ gene fusion constructs after 2-4 hr. Note that more than one independent, stably transformed population was used for each construct. In addition, the staining pattern remained unchanged in experiments performed over a period of several months.

\section{Luciferase activity measurement}

Luciferase activity was assayed as described previously. The Monolight 2001 luminometer, used for these studies, gives a 
Figure 9. Maps of SP60-luciferase and SP60-lac Z constructs. (A) Maps of constructs indicating essential restriction sites. Promoter regions were shifted as cassettes between vectors using the unique $5^{\prime}$-flanking $B g I I I$ site and the unique SpeI site in the SP6O $5^{\prime}$-untranslated region. The Act6-neo ${ }^{R}$ fusion confers G418 resistance. The luciferase vector backbone is vector Cath-Lucl3 (Howard et al. 1988). (B) Sequence around fusion sites between SP60 and luciferase and $\beta$-gal. For the luciferase construct, the SP60 and luciferase ATG are both present and are in-frame. Because out-of-frame luciferase gene constructs show a reduction in expression by several orders of magnitude, we assume the SP60 ATG is used. For $\beta$-gal, the ATG is deleted.

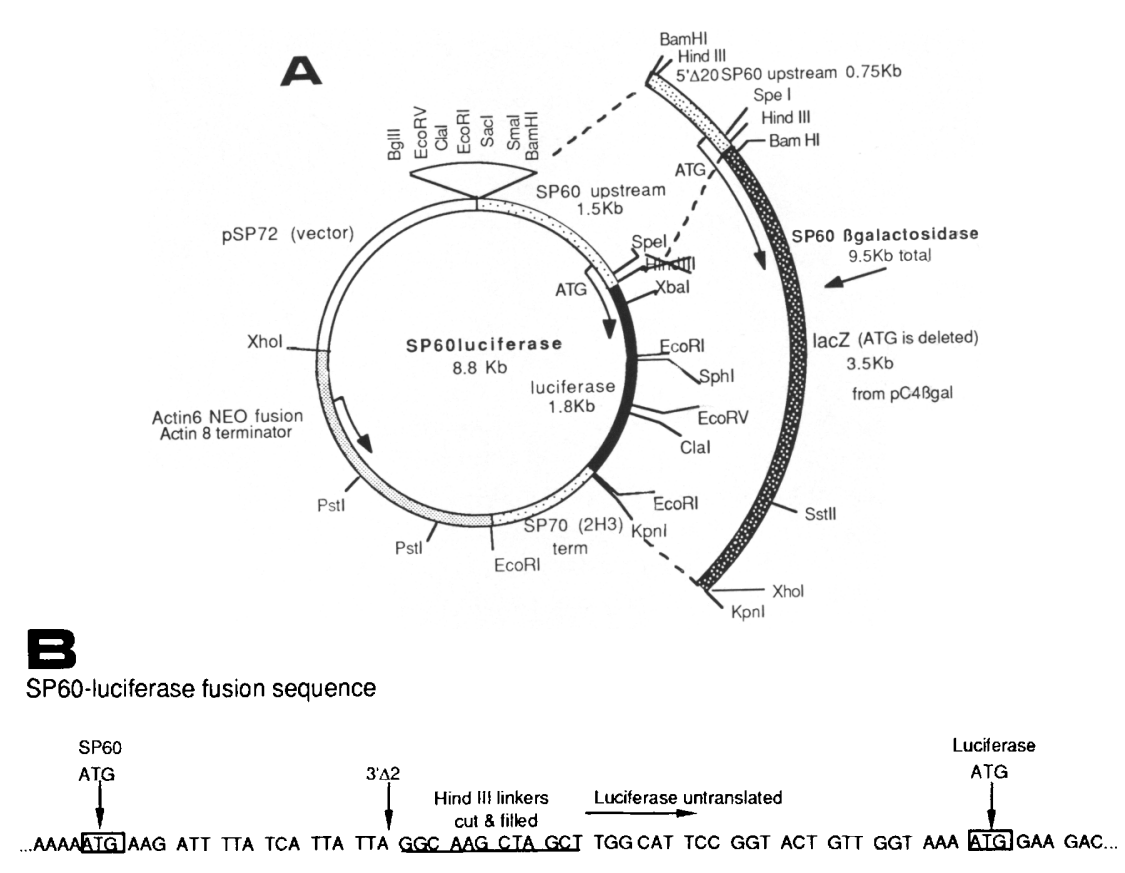

SP60- $\beta$ galactosidase fusion sequence

AAAAIGAAG ATT TAA TCA TIA TAA GGC AAG CT GGG GAT CCC GTC...

linear response up to $10^{6}$ light units (LU). Machine background with either buffer or extracts from untransformed cells is 80-100 LU and was subtracted from the value obtained in each assay. Extracts were diluted, and an aliquot equivalent to between 0.01 and $50 \mu \mathrm{l}$ of the original extract in $300 \lambda$ total was used to obtain light units that ranged between 2,000 and 500,000 per assay. The assay was linear over all dilutions, and luminometer readings were used and performed as described previously (Howard et al. 1988). Total protein amounts were determined using the Bio-Rad protein reagent.

\section{Acknowledgments}

We thank T. Dingermann and J. Williams for providing protocols for $\beta$-gal staining and allowing us to cite their results prior to publication. We thank P. Howard (University of California, San Diegol and members of the 1989 Woods Hole embryology class for some of the $\beta$-gal-stained preparations used in this paper. We also thank J. Williams for recommending pAT153 and for exchange of data on prespore gene regulation and $C$. Zuker for the clones containing the $E$. coli $\beta$-gal gene. We are also grateful to $M$. Karin for helpful suggestions, W.F. Loomis for sharing unpublished results on the sequence of the SP60-coding region, and R.K. Esch and R.T. Hori for insightful and supportive discussions. We thank J. Roth for assistance in preparing the manuscript. L.H. was supported by a National Institutes of Health predoctoral training grant during part of this project. This was work was supported by U.S. Public Health Service grants to R.A.F.

\section{References}

Ahern, K.G., P.K. Howard, and R.A. Firtel. 1988. Identification of regions essential for extrachromosomal replication and maintenance of an endogenous plasmid in Dictyostelium. Nucleic Acids Res. 16: 6825-6837.

Barklis, E. and H.F. Lodish. 1983. Regulation of Dictyostelium discoideum mRNAs specific for prespore and prestalk cells. Cell 32: 1139-1148.

Berk, A.J. and P.A. Sharp. 1977. Sizing and mapping of early adenovirus mRNAs by gel electrophoresis of S1 endonuclease digested hybrids. Cell 12: 721-732.

Blumberg, D.D., J.F. Comer, and K.G. Higinbothem. 1988. A Ca-dependent signal transduction system participates in coupling expression of some cAMP-dependent prespore genes to the cell surface receptor. Dev. Genet. 9: 359-369.

Brookman, J.J., K.A. Jermyn, and R.R. Kay. 1987. Nature and distribution of the morphogen DIF in the Dictyostelium slug. Development 100: 119-124.

Chisholm, R.L., E. Barklis, and H.F. Lodish. 1984. Mechanism of sequential induction of cell-type specific mRNAs in Dictyostelium differentiation. Nature 310: 67-69.

Crowley, T.E., W. Nellen, R. Gomer, and R.A. Firtel. 1985. Phenocopy of discoidin I-minus mutants by anti-sense transformation in Dictyostelium. Cell 43: 633-641.

Datta, S. and R.A. Firtel. 1987. Identification of the sequences controlling cyclic AMP regulation and cell-type specific expression of a prestalk-specific gene in Dictyostelium discoideum. Mol. Cell. Biol. 7: 149-159.

- 1988. An 80 base pair cis-acting regulatory region controls cAMP and developmental regulation of a prestalk gene in Dictyostelium. Genes Dev. 2: 294-304.

Devine, K.M., J.E. Bergmann, and W.F. Loomis. 1983. Spore coat proteins of Dictyostelium discoideum are packaged in prespore vesicles. Dev. Biol. 99: 437-446.

Dingermann, T., N. Reindl, I. Werner, M. Hildebrandt, W. 
Nellen, A. Harwood, J.G. Williams, and K. Nerke. 1990. Optimization and in situ detection of Escherichia coli $\beta$-galactosidase gene expression in Dictyostelium discoideum. Gene (in press).

Dowds, B.C.A. and W.F. Loomis. 1986. Hexapeptide repeat structure in Dictyostelium spore coat protein. Biochem. Biophys. Res. Commun. 135: 336-339.

Driever, W., G. Thoma, and C. Nüsslein-Volhard. 1989. Determination of spatial domains of zygotic gene expression in the Drosophila embryo by the affinity of binding sites for the bicoid morphogen. Nature 340: 363-367.

Dynes, J.L. and R.A. Firtel. 1990. Molecular complementation of a genetic marker in Dictyostelium using a genomic DNA library. Proc. Natl. Acad. Sci. 86: 7966-7970.

Early, A.E. and J.G. Williams. 1988. A Dictyostelium presporespecific gene is transcriptionally repressed by DIF in vitro. Development 103: 519-524.

Early, A.E., J.G. Williams, H.E. Meyer, S.B. Por, E. Smith, K.L. Williams, and A.A. Gooley. 1988. Structural characterization of Dictyostelium discoideum prespore-specific gene D19 and of its product, cell surface glycoprotein PsA. Mol. Cell. Biol. 8: 3458-3466.

Erdos, G.W. and C.M. West. 1989. Formation and organization of the spore coat of Dictyostelium discoideum. Exp. Mycol. 13: $169-182$.

Firtel, R.A., P.J.M. von Haastert, A.R. Kimmel, and P. Devreotes. 1989. G-Protein linked signal transduction pathways in development: Dictyostelium as an experimental system. Cell 58: 235-239.

Fosnaugh, K.L. and W.F. Loomis. 1989. The spore coat genes, SP60 and SP70, of Dictyostelium discoideum. Mol. Cell. Biol. 9: 5215-5218.

Ginsburg, G. and A.R. Kimmel. 1990. Inositol triphosphate and diacylglycerol can differentially modulate gene expression in Dictyostelium. Proc. Natl. Acad. Sci. (in press).

Gomer, R.H. 1987. A strategy to study development and pattern formation: Use of antibodies against products of cloned genes. In Dictyostelium discoideum: Molecular approaches to cell biology (ed. J.A. Spudich), vol. 28, pp. 471-487. Academic Press, New York.

Gomer, R.H. and R.H. Firtel. 1987a. Tissue morphogenesis in Dictyostelium discoideum. In Molecular approaches to developmental biology (ed. R.A. Firtel and E.H. Davidson), pp. 373-383. Alan R. Liss, New York.

- 1987b. Cell-autonomous determination of cell-type choice in Dictyostelium development by cell-cycle phase. Science 237: 758-762.

Gomer, R.H., S. Datta, M. Mehdy, T. Crowley, A. Sivertsen, W. Nellen, C. Reymond, S. Mann, and R.A. Firtel. 1985. Regulation of cell-type-specific gene expression in Dictyostelium. Cold Spring Harbor Symp. Quant. Biol. 50: 801-812.

Gomer, R.H., S. Datta, and R.A. Firtel. 1986a. Cellular and subcellular distribution of a cAMP-regulated prestalk protein and prespore protein in Dictyostelium discoideum: A study on the ontogeny of prestalk and prespore cells. I. Cell Biol. 103: 1999-2015.

Gomer, R.H., D. Armstrong, B.H. Leichtling, and R.A. Firtel. 1986b. cAMP induction of prespore and prestalk gene expression in Dictyostelium is mediated by the cell-surface cAMP receptor. Proc. Natl. Acad. Sci. 83: 8624-8628.

Haribabu, B. and R.P. Dottin. 1986. Pharmacological characterization of cyclic AMP receptors mediating gene regulation in Dictyostelium discoideum. Mol. Cell. Biol. 6: 24022408.

Hjorth, A.L., N.C. Khanna, and R.A. Firtel. 1989. A trans-acting factor required for cAMP-induced gene expression in Dic- tyostelium is regulated developmentally and induced by cAMP. Genes Dev. 3: 747-759.

Hjorth, A.L., C. Pears, J.G. Williams, and R.A. Firtel. 1990. A developmentally regulated trans-acting factor recognizes dissimilar G/C-rich elements controlling a class of cAMPinducible Dictyostelium genes. Genes Dev. 4: 419-432.

Hong, C.B. and W.F. Loomis. 1988. Regulation of SP60 mRNA during development of Dictyostelium discoideum. Biochim. Biophys. Acta 950: 61-66.

Howard, P.K., K.G. Ahern, and R.A. Firtel. 1988. Establishment of a transient expression system for Dictyostelium discoideum. Nucleic Acids Res. 16: 2613-2623.

Janssens, P.M.W. and P.J.M. van Haastert. 1987. Molecular basis of transmembrane signal transduction in Dictyostelium discoideum. Microbiol. Rev. 51: 396-418.

Jermyn, K.A., M. Berks, R.R. Kay, and J.G. Williams. 1987. Two distinct classes of prestalk-enriched mRNA sequences in Dictyostelium discoideum. Development 100: 745-755.

Jermyn, K.A., K.T.I. Duffy, and J.G. Williams. 1989. A new anatomy of the prestalk zone in Dictyostelium. Nature 340: $144-146$.

Kimmel, A.R. 1987. Different molecular mechanisms for cAMP regulation of gene expression during Dictyostelium development. Dev. Biol. 122: 163-171.

Kimmel, A.R. and R.A. Firtel. 1983. Sequence organization in Dictyostelium: Unique structure at the $5^{\prime}$-ends of protein coding genes. Nucleic Acids Res. 11: 541-552.

Krefft, M., L. Voet, J.H. Gregg, H. Mairhofer, and K.L. Williams. 1984. Evidence that positional information is used to establish the prestalk-prespore pattern in Dictyostelium discoideum aggregates. EMBO J. 3: 201-206.

Loomis, W.F., ed. 1982. The development of Dictyostelium discoideum. Academic Press, New York.

MacDonald, S.A. and A.J. Durston. 1984. The cell cycle and sorting behaviour in Dictyostelium discoideum. I. Cell Sci. 66: 195-204.

MacWilliams, H., A. Blaschke, and I. Prause. 1985. Two feedback loops may regulate cell-type proportions in Dictyostelium. Cold Spring Harbor Symp. Quant. Biol. 50: 779-785.

Maniatis, T., E.F. Fritsch, and J. Sambrook. 1982. Molecular cloning: A laboratory manual. Cold Spring Harbor Laboratory, Cold Spring Harbor, New York.

Mann, S. and R.A. Firtel. 1987. Cyclic AMP regulation of early gene expression in Dictyostelium discoideum: Mediation via the cell surface cyclic AMP receptor. Mol. Cell. Biol. 7: 458-469.

Mehdy, M.C. and R.A. Firtel. 1985. A secreted factor and cAMP jointly regulate cell-type-specific gene expression in Dictyostelium. Mol. Cell. Biol. 5: 705-713.

Mehdy, M.C., D. Ratner, and R.A. Firtel. 1983. Induction and modulation of cell-type-specific gene expression in Dictyostelium. Cell 32: 761-771.

Morrissey, J.H., K.M. Devine, and W.F. Loomis. 1984. The timing of cell-type-specific differentiation in Dictyostelium discoideum. Dev. Biol. 103: 414-424.

Oyama, M. and D.D. Blumberg. 1986. Interaction of CAMP with the cell-surface receptor induces cell-type-specific mRNA accumulation in Dictyostelium discoideum. Proc. Natl. Acad. Sci. 83: 4819-4823.

Pears, C.J., H. Mahbubani, and J.G. Williams. 1985. Characterization of two highly diverged but developmentally co-regulated cysteine proteinase genes in Dictyostelium discoideum. Nucleic Acids Res. 13: 8853-8866.

Pears, C.J. and J.G. Williams. 1987. Identification of a DNA sequence element required for efficient expression of a developmentally regulated and cAMP-inducible gene of Dictyos- 
telium discoideum. EMBO J. 6: 195-200.

1988. Multiple copies of a G-rich element upstream of a cAMP-inducible Dictyostelium gene are necessary but not sufficient for efficient gene expression. Nucleic Acids Res. 16: $8467-8486$.

Podgorski, G.J., J. Franke, M. Faure, and R.H. Kessin. 1989. the cyclic nucleotide phosphodiesterase gene of Dictyostelium discoideum utilizes alternate promoters and splicing for the synthesis of multiple mRNAs. Mol. Cell. Biol. 9: 39383950.

Saxe, C.L. III and R.A. Firtel. 1986. Analysis of gene expression in rapidly developing mutants of Dictyostelium discoideum. Dev. Biol. 115: 407-411.

Schaap, P. and R. van Driel. 1985. Induction of post-aggregative differentiation in Dictyostelium discoideum by cAMP. Exp. Cell Res. 159: 388-398.

Schaap, P. and M. Wang. 1986. Interactions between adenosine and oscillatory cAMP signaling regulate size and pattern in Dictyostelium. Cell 45: 137-144.

Schaap, P., M. van Lookeren Campagne, R. van Driel, W. Spek, P.J.M. van Haastert, and J. Pinas. 1986. Postaggregative differentiation induction by cyclic AMP in Dictyostelium: Intracellular transduction pathway and requirement for additional stimuli. Dev. Biol. 118: 52-63.

Spek, W., K. van Drunen, R. van Eijk, and P. Schaap. 1988. Opposite effects of adenosine on two types of cAMP-induced gene expression in Dictyostelium indicate the involvement of at least two different intracellular pathways for the transduction of cAMP signals. FEBS Lett. 228: 231-234.

Struhl, G., K. Struhl, and P.M. Macdonald. 1989. The gradient morphogen bicoid is a concentration-dependent transcriptional activator. Cell 57: 1259-1273.

Takemoto, K., A. Yamamoto, and I. Takeuchi. 1985. The origin of prespore vacuoles in Dictyostelium discoideum cells as analysed by electron-microscopic immunocytochemistry and radioautography. J. Cell Sci. 77: 93-108.

Takeuchi, I. 1963. Immunochemical and immunohistochemical studies on the development of the cellular slime mold Dictyostelium discoideum. Dev. Biol. 8: 1-26.

Tasaka, M., T. Noce, and I. Takeuchi. 1983. Prestalk and prespore differentiation in Dictyostelium as detected by cell type-specific monoclonal antibodies. Proc. Natl. Acad. Sci. 80: $5340-5344$,

Wang, M., R. van Driel, and P. Schaap. 1988a. Cyclic AMPphosphodiesterase induces dedifferentiation of prespore cells in Dictyostelium discoideum slugs: Evidence that cyclic AMP is the morphogenetic signal for prespore differentiation. Development 103: 611-618.

Wang, M., P.J.M. van Haastert, and P. Schaap. 1988b. Multiple effects of differentiation-inducing factor on prespore differentiation and cyclic-AMP signal transduction in Dictyostelium. Differentiation 33: 24-28.

Weijer, C.J., G. Duschl, and C.N. David. 1984. Dependence of cell-type proportioning and sorting on cell cycle phase in Dictyostelium discoideum. I. Cell Sci. 70: 133-145.

Williams, G.B., E.M. Elder, and M. Sussman. 1984. Modulation of the cAMP relay in Dictyostelium discoideum by ammonia and other metabolites: Possible morphogenetic consequences. Dev. Biol. 105: 377-388.

Williams, J.G. 1988. The role of diffusible molecules in regulating the cellular differentiation of Dictyostelium discoideum. Development 103: 1-16.

Williams, J.G., A.S. Tsang, and H. Mahbubani. 1980. A change in the rate of transcription of a eukaryotic gene in response to cyclic AMP. Proc. Natl. Acad. Sci. 77: 7171-7175.

Williams, I.G., M.J. North, and H. Mahbubani. 1985. A develop- mentally regulated cysteine proteinase in Dictyostelium discoideum. EMBO J. 4: 999-1006.

Williams, J.G., A. Ceccarelli, S. McRobbie, H. Mahbubani, R.R. Kay, A. Early, M. Berks, and K.A. Jermyn. 1987. Direct induction of Dictyostelium prestalk gene expression by DIF provides evidence that DIF is a morphogen. Cell 49: 185192.

\section{Note added in proof}

Sequence data described in this paper have been submitted to the EMBL/GenBank Data Libraries under accession number $\mathrm{X} 52105$. 


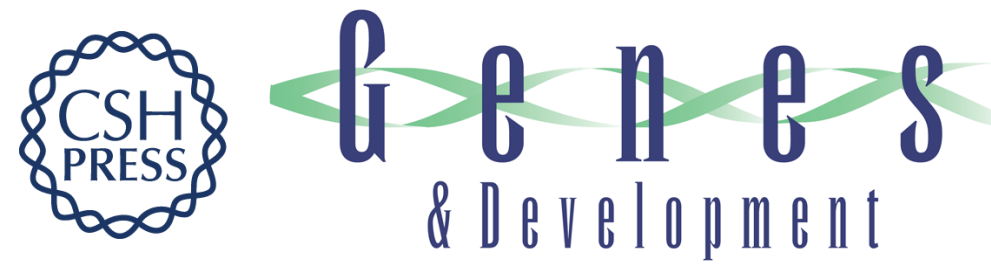

\section{A spatial gradient of expression of a cAMP-regulated prespore cell-type-specific gene in Dictyostelium.}

L Haberstroh and R A Firtel

Genes Dev. 1990, 4:

Access the most recent version at doi:10.1101/gad.4.4.596

References This article cites 61 articles, 27 of which can be accessed free at:

http://genesdev.cshlp.org/content/4/4/596.full.html\#ref-list-1

License

Email Alerting

Service

Receive free email alerts when new articles cite this article - sign up in the box at the top right corner of the article or click here.

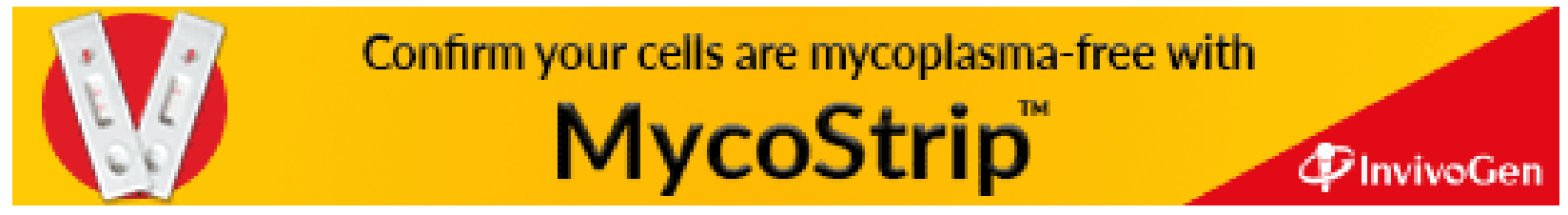

